\title{
Journal of

\section{Synthesis, Structural Elucidation, and Biological Evaluation of NSC12, an Orally Available Fibroblast Growth Factor (FGF) Ligand Trap for the Treatment of FGF-Dependent Lung Tumors}

Riccardo Castelli, ${ }^{\ddagger}$ Arianna Giacomini, ${ }^{\S}$ Mattia Anselmi, ${ }^{\ddagger}$ Nicole Bozza, ${ }^{\ddagger}$ Federica Vacondio, ${ }^{\ddagger}$ Silvia Rivara, ${ }^{\ddagger}$ Sara Matarazzo, ${ }^{\S}$ Marco Presta, ${ }^{*}$, Marco Mor, ${ }^{*} \neq$ and Roberto Ronca ${ }^{*}$,

"Dipartimento di Farmacia, Università degli Studi di Parma, Parco Area delle Scienze 27/A, I-43124, Parma, Italy

${ }^{\S}$ Dipartimento di Medicina Molecolare e Traslazionale, Università degli Studi di Brescia, Via Branze 39, I-25123, Brescia, Italy

Supporting Information

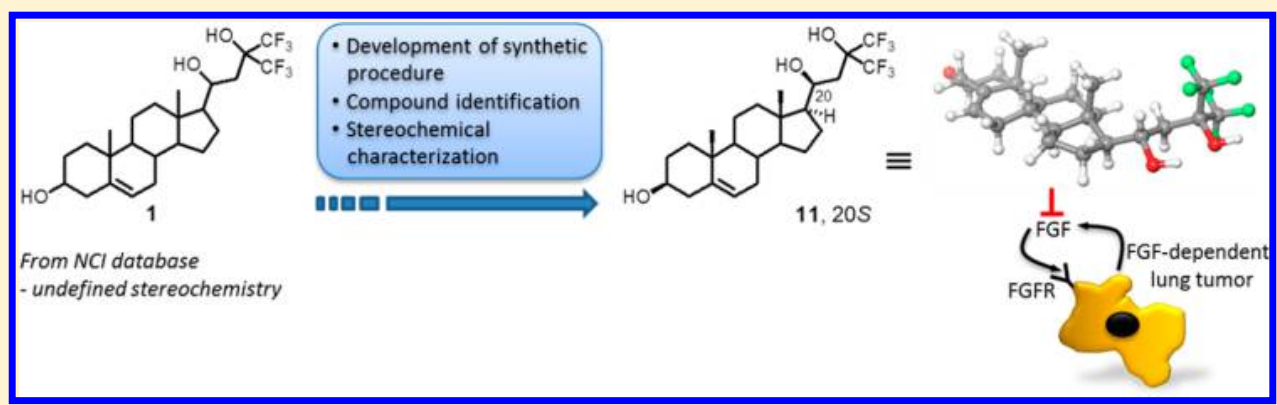

ABSTRACT: NSC12 is an orally available pan-FGF trap able to inhibit FGF2/FGFR interaction and endowed with promising antitumor activity. It was identified by virtual screening from a NCI small molecule library, but no data were available about its synthesis, stereochemistry, and physicochemical properties. We report here a synthetic route that allowed us to characterize and unambiguously identify the structure of the active compound by a combination of NMR spectroscopy and in silico conformational analysis. The synthetic protocol allowed us to sustain experiments aimed at assessing its therapeutic potential for the treatment of FGF-dependent lung cancers. A crucial step in the synthesis generated a couple of diastereoisomers, with only one able to act as a FGF trap molecule and to inhibit FGF-dependent receptor activation, cell proliferation, and tumor growth when tested in vitro and in vivo on murine and human lung cancer cells.

\section{INTRODUCTION}

Fibroblast growth factors (FGFs) are members of a large family of structurally related proteins that affect growth, differentiation, migration, and survival of a variety of cell types by leading the formation of productive ternary complexes with signaling FGF receptors (FGFRs) and cell-surface heparan sulfate proteoglycans (HSPGs). ${ }^{1-3}$

FGFs are highly expressed in epithelial human tumors where they modulate growth, neovascularization, metastatic spreading, and drug resistance. ${ }^{4}$ In lung cancer, the activation of the FGF/ FGFR signaling pathway promotes cancer cell survival, resistance to chemotherapy, and growth of small- and nonsmall-cell lung tumors. ${ }^{5}$ Elevated serum concentrations of FGF2 represent an unfavorable prognostic factor in lung cancer, ${ }^{6}$ while amplification of the FGFR1 gene is a frequent feature of squamous cell carcinomas in smoking patients. Thus, the FGF/FGFR system represents a privileged target for the therapeutic approach of lung tumors in which the FGFdependent activation of FGFR is an oncogenic factor.

Current pharmacological approaches to address the inhibition of the FGF/FGFR system include tyrosine-kinase inhibitors (TKIs) and anti-FGFR antibodies or peptides. ${ }^{8}$ Multitarget TKIs that inhibit FGFR signaling are used in the clinic and selective FGFR TKIs are evaluated in clinical trials. However, both selective and nonselective TKIs show significant side effects. ${ }^{9}$ An alternative approach aimed at preventing FGF binding to its cognate receptors is the use of ligand traps. ${ }^{10}$

Recently, we reported the characterization of the interaction between FGF2 and its endogenous binder long-pentraxin 3 $(\mathrm{PTX} 3)^{11}$ and identified a 5-mer peptide belonging to the amino-terminal sequence of PTX3 as the minimal motif needed to bind FGF2 and to block its biological activity. ${ }^{12}$ The pentapeptide was used for the modeling of a pharmacophore, which in turn was used to screen the NCI2003 library of small molecules. $^{13}$ 4,4,4-Trifluoro-1-(3-hydroxy-10,13-dimethyl$2,3,4,7,8,9,11,12,14,15,16,17$-dodecahydro- $1 H$-cyclopenta[a]phenanthren-17-yl)-3-(trifluoromethyl)butane-1,3-diol (compound 1 in Scheme 1, deposited at NCI with the code number NSC172285 and named NSC12) was identified from this screening as a low molecular weight compound able to act as a pan-FGF trap. This property resulted in a potent antiangiogenic and antitumor activity when tested in various FGF-dependent tumor models, designating $\mathbf{1}$ as the first nonpeptidic, orally

Received: December 29, 2015

Published: May 3, 2016 
Scheme 1. Retrosynthetic Analysis for Compound 1

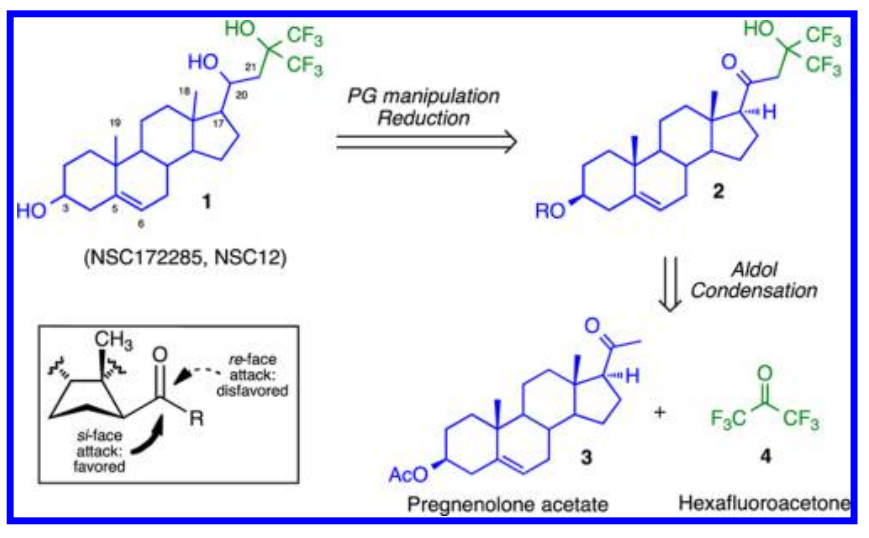

available small molecule FGF trap endowed with potential implications for the therapy of FGF-dependent cancers. ${ }^{14}$ However, a survey of the available information provided minimal data for this compound, with no details regarding its stereochemistry and its preparation, purification, and characterization. We report here the synthesis of $\mathbf{1}$, designed on the sole structure provided by the NCI, the assignment of its absolute configuration, in vitro and in vivo experiments that confirmed its biological activity, and characterization of its physicochemical properties and oral bioavailability.

\section{RESULTS}

Synthesis. Retro-synthetic analysis of 1 dissects the molecule into the steroidal portion and the 1,1-bis-trifluoromethyl-1,3-propanediol motif, deriving in turn from the reduction of the $\beta$-hydroxy ketone 2 (Scheme 1 ) and some minor protecting group manipulation. Following the disconnection at C21, compound $\mathbf{2}$ derives its carbon backbone from the aldol condensation of a suitably protected derivative of commercially available pregnenolone acetate 3 and hexafluoroacetone (HFA) $4 .^{15}$ We were confident that reduction of the $\beta$-hydroxy ketone would furnish the 1,3-propanediol fragment in high stereoselectivity, assuming as a first hypothesis that $\mathbf{1}$ had been produced employing conditions that favor attack of the reducing nucleophile on the $s i$-face of the keto group. ${ }^{16}$

Before engaging it in the aldol condensation, pregnenolone acetate 3 was converted to the corresponding benzoate (Scheme 2, compound 6) by means of transesterification and subsequent benzoylation of the hydroxyl group of intermediate 5.

The optimized protocol featured the generation of the lithium enolate of pregnenolone benzoate 6 with freshly prepared LiHMDS in anhydrous THF at $-78{ }^{\circ} \mathrm{C}$ and warming to $0{ }^{\circ} \mathrm{C}$ for a few minutes ${ }^{17}$ and then promptly delivering HFA to the cold $\left(-78{ }^{\circ} \mathrm{C}\right)$, stirred solution of lithium enolate. ${ }^{18}$ After quenching of the reaction and aqueous workup, the product could be isolated in up to $76 \%$ yield. The reduction of the carbonyl function was straightforwardly accomplished by treatment of $\beta$-hydroxy ketone 7 with $\mathrm{NaBH}_{4}$ in a mixture of methanol and THF (Scheme 2) to furnish 8 as a single isomer. ${ }^{19}$ After saponification of the benzoate ester, compound 9 was tested in vitro to evaluate its cytotoxicity, resulting in it being devoid of significant biological activity.

To rationalize why 9 behaved differently from the compound provided by the NCI, we set out to perform structural analysis. Whereas ESI-MS spectra showed identical molecular ion peak and fragmentation pattern for the two substances, HPLC
Scheme $2^{a}$

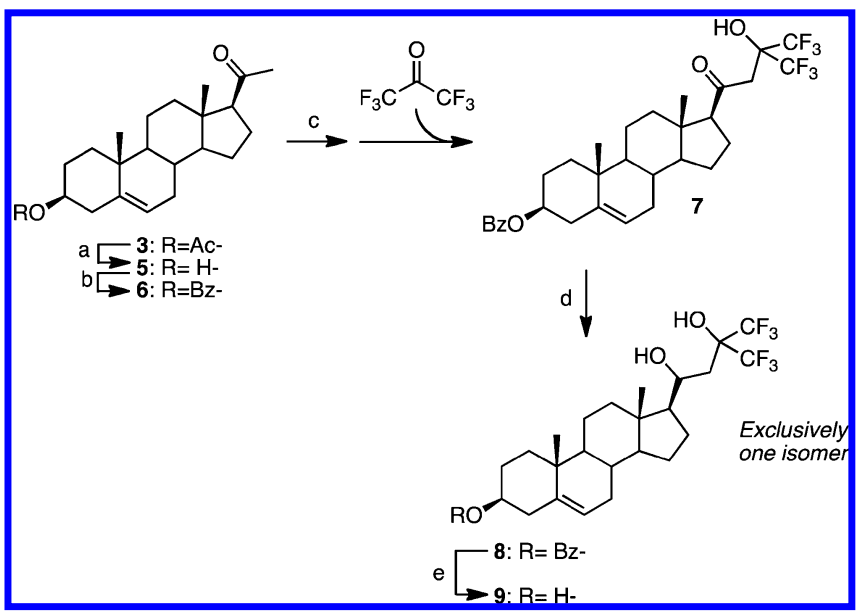

${ }^{a}$ Reagents and conditions: (a) MeONa, $\mathrm{MeOH}$, rt; (b) BzCl, pyridine, DMAP cat., rt, $86 \%$ yield over two steps; (c) (i) $\left(\mathrm{Me}_{3} \mathrm{Si}\right) \mathrm{NLi}$, THF, -78 to $0{ }^{\circ} \mathrm{C}$ (ii) HFA, $-78{ }^{\circ} \mathrm{C}$ to rt; $78 \%$ yield; (d) $\mathrm{NaBH}_{4}, \mathrm{MeOH} /$ THF 1:1; (e) MeONa, MeOH, rt, $68 \%$ yield over two steps.

analysis showed a different retention time of 9 with respect to 1 (co-injection as shown in Figure 1). Inspection of the ${ }^{1} \mathrm{H}$ NMR

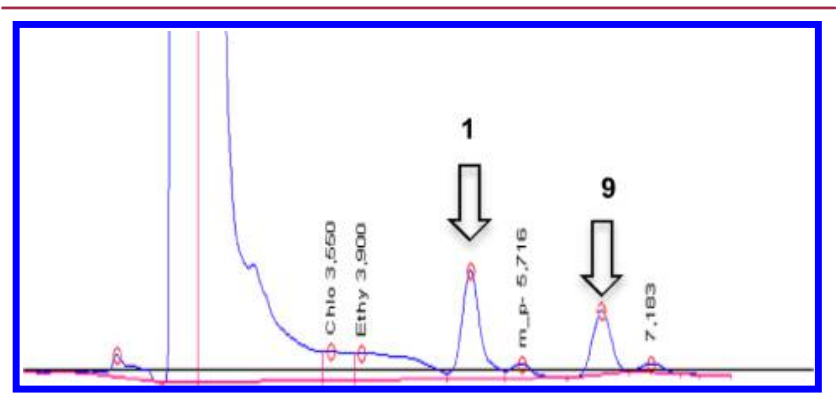

Figure 1. HPLC trace of a co-injection of compounds 9 and $\mathbf{1}$ showing different retention times.

spectrum of both compounds revealed few small but appreciable differences in some key regions of the spectrum. Remarkably, the chemical shift of the H18 methyl group is about $0.3 \mathrm{ppm}$ different and a doublet of triplet at $2.10 \mathrm{ppm}$ (H12eq) is clearly visible in the spectrum of compound 9 while absent in that of 11 (see Supporting Information Figure 4). The signal of $\mathrm{H} 20$ for both compounds is almost perfectly superimposable. We hypothesized that compounds 9 and $\mathbf{1}$ were diastereoisomers, and given that the only stereocenter generated during the synthesis was $\mathrm{C} 20$, we located the origin of the epimeric nature of the two compounds at the reduction step. $^{20}$

After screening of a variety of reducing agents $\left(\mathrm{LiAlH}_{4}\right.$, Luche reduction, DiBAL-H, among others), the only one capable of delivering useful quantities (dr 87:13, 8/10) of both diastereoisomers was sodium triacetoxyborohydride, by virtue of an intramolecular rather than intermolecular reaction (Scheme 3). ${ }^{21}$ All the other common reducing agents consistently furnished exclusively the major isomer 8, precursor to 9. Attempts to invert the configuration at $\mathrm{C} 20$ of compound 8 (sulfonylation/nucleophilic substitution, cyclic sulfate formation/nucleophilic substitution, Mitsunobu conditions) failed to deliver any useful precursor of $\mathbf{1}$. 
Scheme $3^{a}$

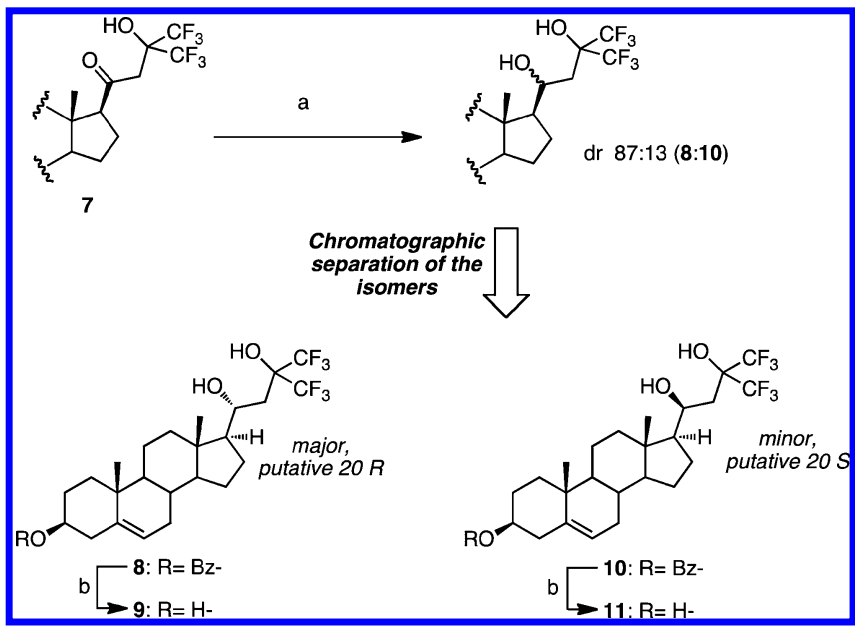

${ }^{a}$ Reagents and conditions: (a) $\mathrm{Na}(\mathrm{AcO}){ }_{3} \mathrm{BH}, \mathrm{MeOH} / \mathrm{THF} \mathrm{MeOH}$, rt; (b) $\mathrm{MeONa}, \mathrm{MeOH}$, rt, $74 \%$ yield for $\mathbf{9}, \mathbf{1 1} \%$ for $\mathbf{1 1}$ over two steps.

After careful chromatographic separation with standard flash column chromatography, followed by separation of the mixture enriched of the minor isomer with an automated MPLC system, reasonable quantities of the two epimers $\mathbf{8}$ and $\mathbf{1 0}$ could be obtained and then deprived of the benzoate ester by transesterification with catalytic $\mathrm{MeONa}$ in $\mathrm{MeOH}$ to afford products 9 and $\mathbf{1 1}$. We could finally prove the identity of $\mathbf{1 1}$ and 1 spectroscopically by means of ${ }^{1} \mathrm{H}$ and ${ }^{13} \mathrm{C}$ NMR analysis and chromatographically (HPLC-MS/MS; see Supporting Information).

NMR Analysis. After establishment that compound $\mathbf{1 1}$ is identical to $\mathbf{1}$, the substance provided by the NCI, and that compound 9 is the corresponding C20 epimer, the absolute configuration of the two compounds at $\mathrm{C} 20$ was assigned. Inspection of ${ }^{1} \mathrm{H}$ NMR spectra revealed the peculiar multiplicity of H20, a triplet signal for both compounds 9 and $\mathbf{1 1}$. The coupling constant ${ }^{3} \mathrm{~J}$ is $10.3 \mathrm{~Hz}$. H20 is neighbored by three vicinal protons $(\mathrm{H} 17, \mathrm{H} 21 \mathrm{a}, \mathrm{H} 2 \mathrm{~b})$, meaning that such an unexpected low multiplicity arises from (i) a null-coupling constant with one of the three protons and (ii) two couplings of equal magnitude. ${ }^{1} \mathrm{H}$ TOCSY experiment with selective band center irradiation on $\mathrm{H} 20$ allowed observing that $\mathrm{H} 21$ a has only one geminal $\left({ }^{2} J\right)$ coupling with $\mathrm{H} 21 \mathrm{~b}(J=15.0 \mathrm{~Hz})$, in turn resonating as canonical doublet-of-doublet $A B$ system with coupling constants of 15.0 and $10.3 \mathrm{~Hz}$, respectively. Therefore, $\mathrm{H} 21 \mathrm{a}$ has the null coupling with $\mathrm{H} 20{ }^{22}$ According to the Karplus equation, ${ }^{23}$ the dihedral angle between these protons should be close to $90^{\circ}$, meaning that $\mathrm{H} 20$ should assume an anti arrangement with both $\mathrm{H} 17$ and $\mathrm{H} 21 \mathrm{~b}$ and suggests a conformationally locked, six-membered ring induced by an intramolecular hydrogen bond involving the hydroxyl groups of the 1,3-diol portion (Figure 2).

The coupling constants calculated by the software Schrödinger Maestro $9.7^{24}$ for H20 on the minimum-energy geometries represented in Figure 2, in which the hydrogen bond between the two hydroxyl groups is formed, were consistent with the observed triplets. In particular, the calculated values for $\mathrm{H} 20-\mathrm{H} 17, \mathrm{H} 20-\mathrm{H} 21 \mathrm{a}$, and $\mathrm{H} 20-\mathrm{H} 21 \mathrm{~b}$ were 9.9, 1.0, and $11.0 \mathrm{~Hz}$ for 9 and $9.7,1.5$, and $11.3 \mathrm{~Hz}$ for 11, respectively. From the minimized geometries of the compounds with $20 R$ and $20 S$ stereochemistry (Figure 2) it is possible to appreciate the enantiomorphic arrangement of

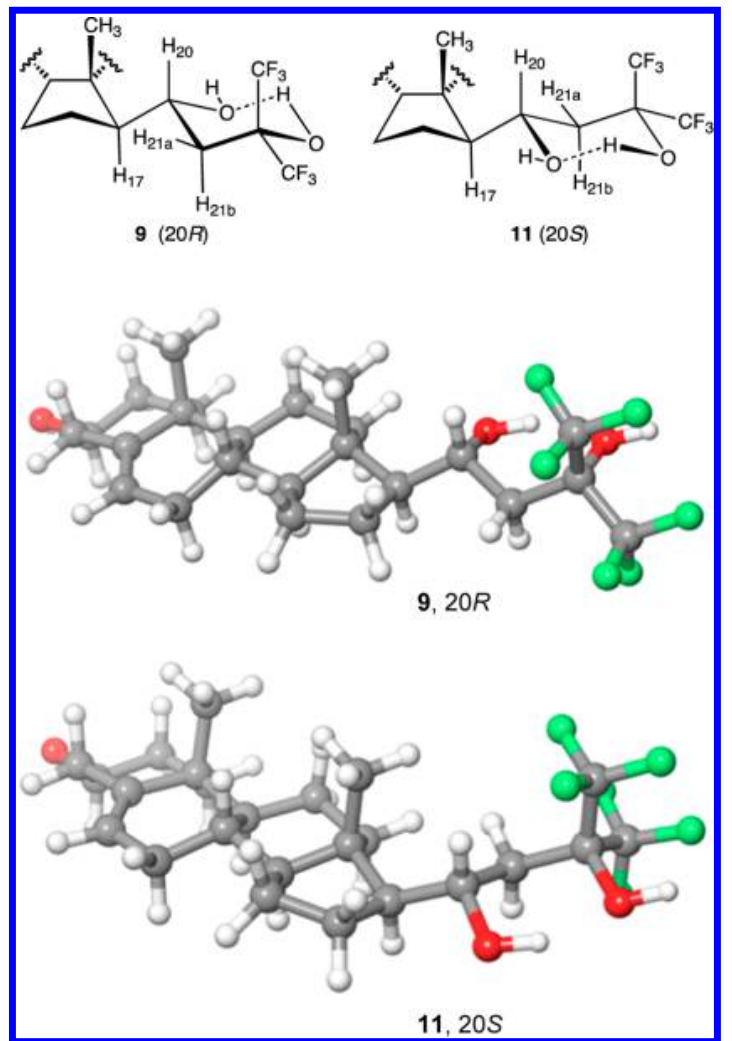

Figure 2. Proposed preferential conformations and geometries for compounds 9 and 11.

functional groups, in which the remarkable difference in the distance between the $\mathrm{C} 18$ methyl group and the $\mathrm{C} 21$ methylene suggested the use of nuclear Overhauser effect (NOE) NMR experiments to identify the two epimers. ${ }^{25}$

NOE-NMR spectra of both compounds showed a clear contact between $\mathrm{H} 18$ hydrogens and H20, indicating a comparable relative distance. While compound $\mathbf{1 1}$ showed a NOE contact between $\mathrm{H} 18$ and $\mathrm{H} 21 \mathrm{a}$ at $2.18 \mathrm{ppm}$, compound 9 showed a signal at $2.05 \mathrm{ppm}$ that could not be unequivocally identified by 2D-COSY nor by HSQC-NMR experiments, due to extensive signal overlapping from protons of the steroidal skeleton (Figure 3). We thus decided to engage the C20 and C22 hydroxyl groups in a six-membered cyclic carbonate (Scheme 4) to shift some of the critical signals in the NMR spectra and "freeze" the conformation accessible to the 1,3-diol portion. ${ }^{26,27}$ The energy-minimized geometries of carbonates 12 and 13 (Figure 4) allowed the calculation of the distance between $\mathrm{H} 21 \mathrm{a}$ and $\mathrm{H} 18$, found to be 4.33 and $2.46 \AA$ for the $20 \mathrm{R}$ and $20 \mathrm{~S}$ carbonates, respectively. ${ }^{1} \mathrm{H}$ NMR analysis of cyclic carbonates showed that $\mathrm{H} 20$ retained the triplet multiplicity and that the critical pseudoequatorial H21a signal was in a region of the spectrum free of other resonance peaks. The results of NOE experiments are depicted in Figure 5. H18 of compound 12 showed NOE contacts with H19 $(d=2.95 \AA$, calculated from molecular model), H16 (d=2.43 $)$, H11ax $(d$ $=2.18 \AA), \mathrm{H} 8(d=2.17 \AA), \mathrm{H} 12 \mathrm{eq}(d=2.53 \AA)$, and H20 ( $d=$ $2.35 \AA)$; the unequivocal assignment of these signals was accomplished by $2 \mathrm{D}$-COSY and HSQC-NMR experiments, and these results are consistent with the proposed conformation (Supporting Information Figure 8). As expected, no contact was observed between H21eq (2.42 ppm) and $\mathrm{H} 18$ of compound 12. On the contrary, H18 of compound 13, in 


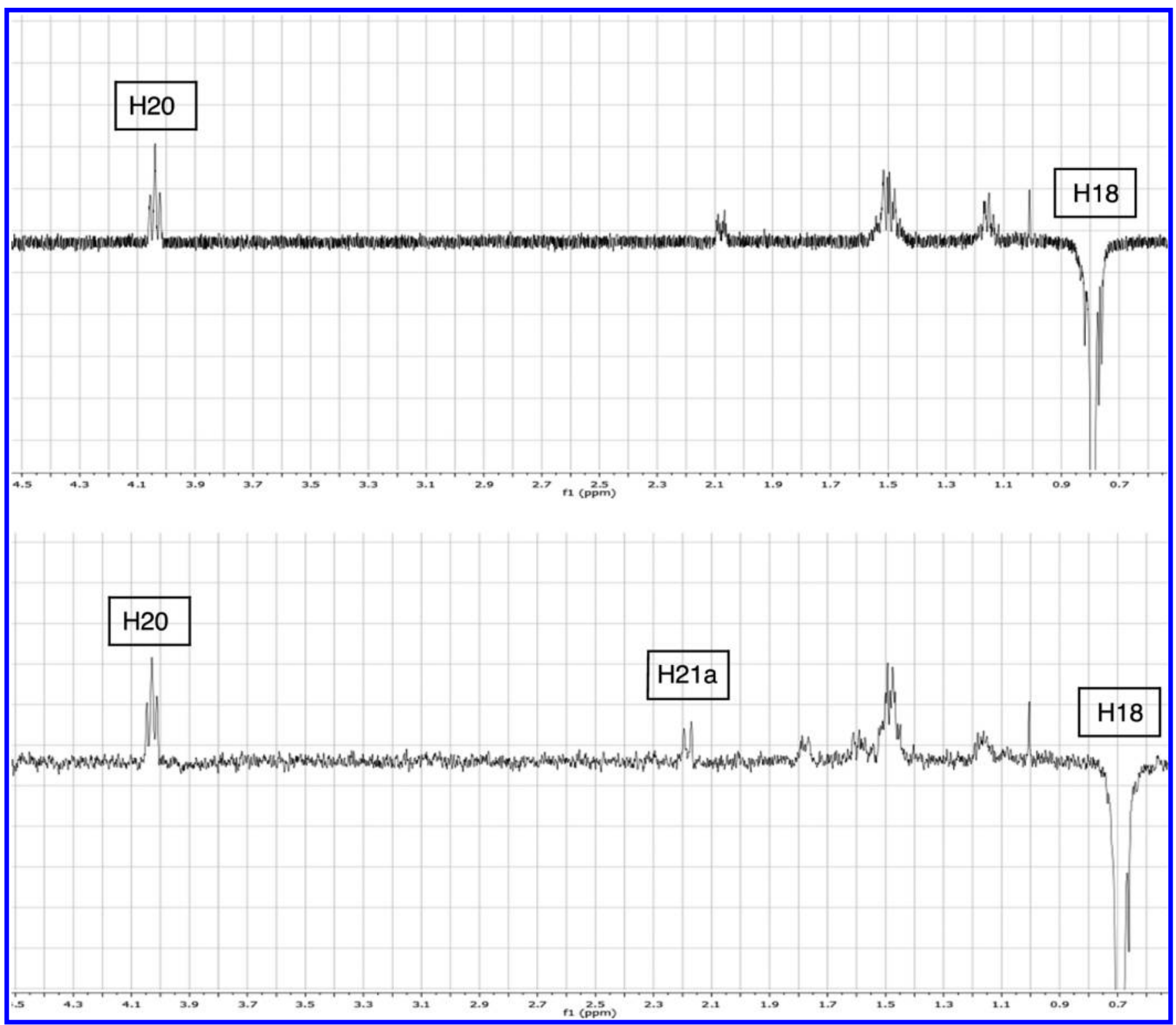

Figure 3. 1D NOE-NMR spectra of compounds $\mathbf{9}$ (top) and $\mathbf{1 1}$ (bottom) with selective band center irradiation on H18.

\section{Scheme $4^{a}$}

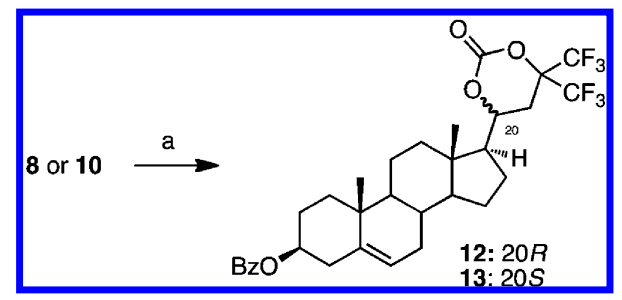

${ }^{a}$ Reagents and conditions: (a) triphosgene, pyridine, $-50{ }^{\circ} \mathrm{C}, 77 \%$ yield for $12,68 \%$ yield for 13 .

addition to showing the expected NOE contacts with $\mathrm{H} 19(d=$ $2.96 \AA), \mathrm{H} 8(d=2.17 \AA), \mathrm{H} 16(d=2.43 \AA), \mathrm{H} 11 \mathrm{ax}(d=2.18$ $\AA)$, and $\mathrm{H} 20(d=2.41 \AA)$, showed a distinct NOE contact with H21eq $(d=2.46 \AA)$, as predicted from the molecular models (see Supporting Information Figures 12 and 13). We therefore concluded that the cyclic carbonate 12, deriving from compound $\mathbf{8}$, the major isomer obtained from the reduction step, has $20 R$ configuration, whereas 13 , the cyclic carbonate

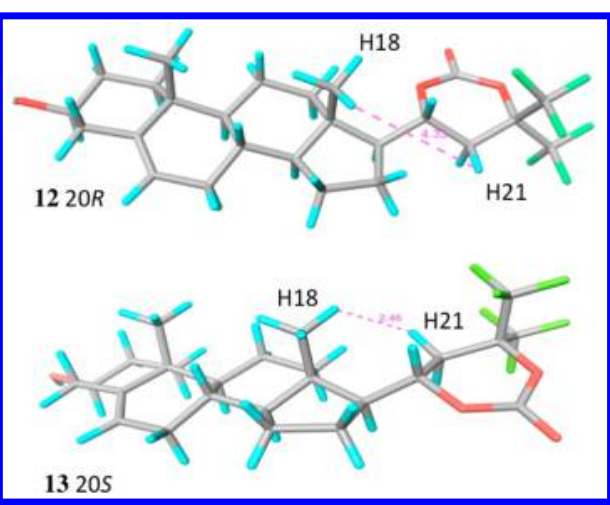

Figure 4. Minimized geometries for compounds 12 (top) and 13 (bottom). Distances between $\mathrm{H} 21$ eq and the closest $\mathrm{C} 18$ hydrogen are the following: 12, $4.33 \AA$; 13, $2.46 \AA$ A. 3-Benzoyl esters are omitted for clarity.

obtained from compound 10, the minor isomer, has $20 S$ configuration. Given that the absolute configuration at C20 was 


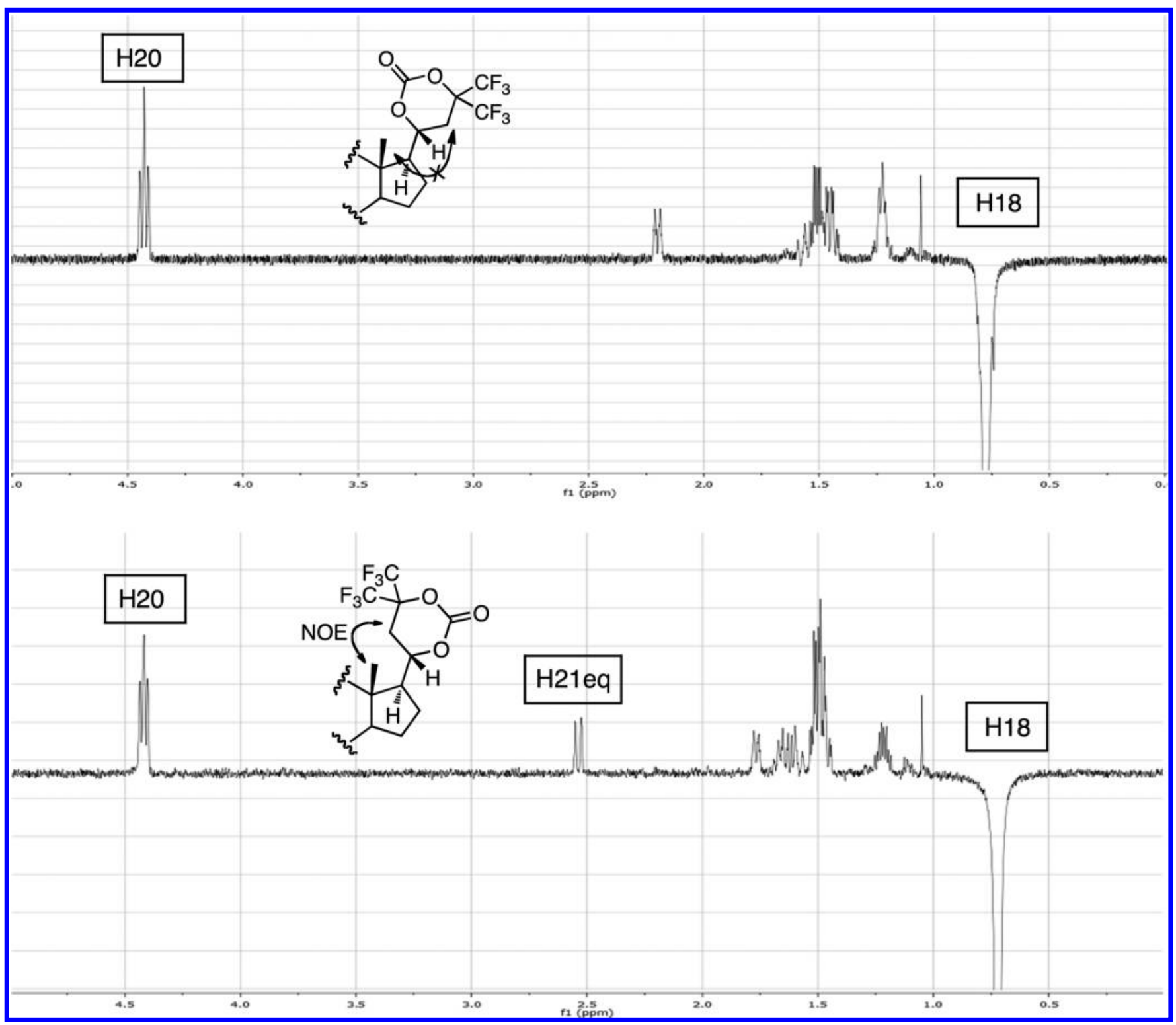

Figure 5. 1D NOE-NMR spectra of compounds 12 (top) and 13 (bottom) with selective band center irradiation on H18.

not affected during the generation of the cyclic carbonate, we also concluded that compound 11, identical to $\mathbf{1}$, has $20 \mathrm{~S}$ configuration (Figure 2).

Molecular Interactions and Docking Simulations. Compound 1 exerts its FGF2 trap activity by binding to the growth factor molecule, thus hampering FGF/FGFR interaction. On this basis, DMSO stock solutions of 9 and 11 were diluted in PBS, keeping the final concentration of DMSO at $3 \%$, and their capacity to bind FGF2 was assessed by surface plasmon resonance (SPR) spectroscopy. In parallel, their solubility was evaluated under the same experimental conditions. Similar to $\mathbf{1},{ }^{14}$ compound $\mathbf{1 1}$ binds FGF2 immobilized to a BIAcore sensor chip in a dose-dependent manner with an apparent $K_{\mathrm{d}}$ value equal to $\sim 40 \mu \mathrm{M}$ (Figure 6). When assessed for its solubility, 11 was fully soluble in the 3\% DMSO solution up to the concentration of $30 \mu \mathrm{M}$, its solubility decreasing at higher concentrations, whereas compound 9 was significantly less soluble. When compared to 11, compound 9 appeared to be unable to interact with immobilized FGF2 at any concentration tested, even when dissolved at a nominal 100

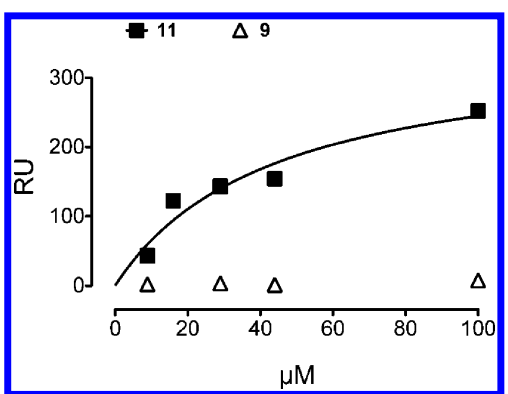

Figure 6. SPR analysis of compounds 9 and 11 on a FGF2-coated sensor chip.

$\mu \mathrm{M}$ concentration, which corresponds to an actual concentration of $25 \mu \mathrm{M}$ in 3\% DMSO solution (Figure 6 and Supporting Information Figure 14).

A binding mode for compound 1-FGF2, based on docking and molecular dynamics simulations and supported by NMR data, has been described. ${ }^{14}$ Thus, docking simulations that took into account published information were used to explore the 
possibility that this binding mode could explain the different FGF2-binding capacity of the two diasteroisomers. To this aim, starting from a crystal structure of FGF2 (see Experimental Section), only solutions involving the surface around key residues were considered. Among the first 100 nonredundant docking poses of compound $\mathbf{1 1}$ having polar interactions with Glu96, one presented all the features previously described, i.e., the butyl chain and trifluoromethyl groups within the hydrophobic patch defined by Leu55, Ala57 and Val63; the hydroxyl group on C20 taking a hydrogen bond with Glu96; packing of rings $\mathrm{A}$ and $\mathrm{B}$ of the steroid scaffold with Leu107. In this pose, the ligand occupies the portion of FGF2 surface that faces the linker between FGFR1-D2 and D3 in the crystallized structure (Figure 7).

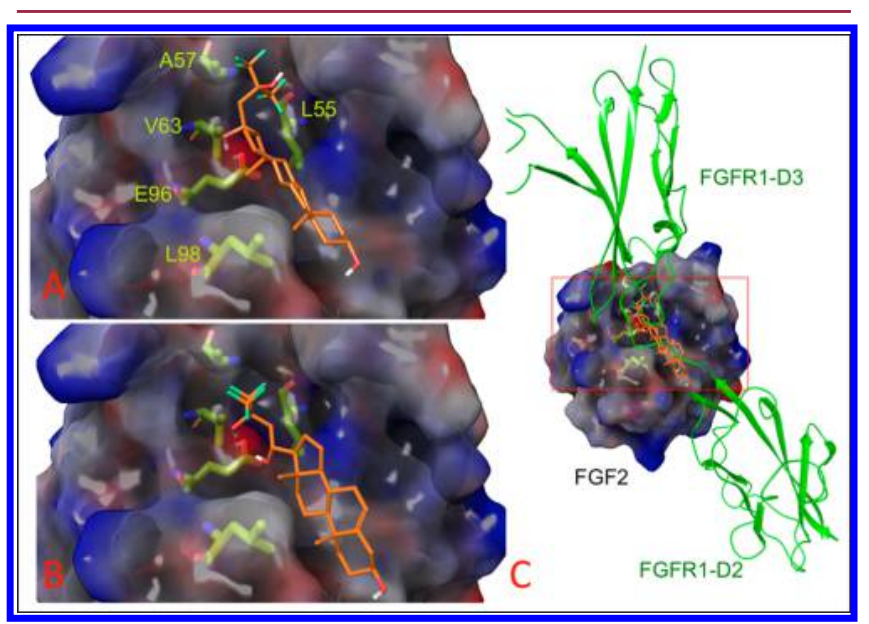

Figure 7. (A) Docking solution of compound 11 (orange carbons) on FGF2 surface. Amino acids reported to interact with the ligand are shown (green carbons). The colors of FGF2 surface are related to molecular electrostatic potential. (B) Docking solution of compound 9 (orange carbons) on FGF2 surface. (C) View of the FGF2-FGFR1 (green ribbons) complex, as observed in the crystallized structure $1 \mathrm{fq} 9$, with docked structures of compounds $\mathbf{9}$ and $\mathbf{1 1}$.

Application of the same docking protocol to compound 9 gave a similar pose, with both the hydroxyl groups on the ligand chain interacting with the carboxylate group of Glu96, while the steroid nucleus projected toward the FGFR1-D2-interacting side. In both cases, the docking solutions presented docking scores significantly lower than the best poses $(-1.6$ vs -3.5 for compound $20 \mathrm{~S}$ and $-2.1 \mathrm{vs}-3.5 \mathrm{kcal} / \mathrm{mol}$ for $20 \mathrm{R}$ ) that pointed the steroid nucleus toward the FGFR1-D3-interacting area and were therefore less consistent with reported NMR data.

In conclusion, compounds 9 and $\mathbf{1 1}$ can be docked on the FGF2 surface in a binding mode that, even though consistent with previous observations, does not explain the different FGF2-binding affinity of the two diasteroisomers. Given the uncertainty of virtual docking models, further structural or structure-activity information will be required to elucidate unambiguously the mode of interaction of the two compounds with the FGF2 molecule.

In Vitro Studies. Given their different FGF2-binding potential, compounds $\mathbf{9}$ and $\mathbf{1 1}$ were compared to $\mathbf{1}$ for their capacity to prevent the formation of HSPG/FGF2/FGFR1 ternary complexes in a FGF2-mediated cell-cell adhesion assay. ${ }^{12 \mathrm{~b}}$ The results demonstrate that $\mathbf{1}$ and $\mathbf{1 1}$ dissolved in 3\% DMSO hamper the formation of $\mathrm{HSPG} / \mathrm{FGF} 2 / \mathrm{FGFR}$ complexes with an $\mathrm{IC}_{50}$ equal to $\sim 10 \mu \mathrm{M}$, whereas 9 was inactive also when tested at a nominal $100 \mu \mathrm{M}$ concentration (Figure $8 \mathrm{~A}$ ), corresponding to an actual $25 \mu \mathrm{M}$ concentration (see above). Accordingly, when tested under the same experimental conditions, compound 11, but not 9, inhibited FGFR1 phosphorylation triggered by FGF2 in Lewis lung carcinoma (LLC) cells in a manner similar to $\mathbf{1}$ (Figure 8B). As a consequence, compounds $\mathbf{1 1}$ and $\mathbf{1}$ efficiently impaired the proliferation of FGF-dependent murine (LLC) and human (H520) lung carcinoma cell lines in vitro with an identical $\mathrm{IC}_{50}$ value, equal to $2.0 \mu \mathrm{M}$ and $4.1 \mu \mathrm{M}$, respectively (Figure $8 \mathrm{C}$ ). In contrast, compound 9 did not exert a significant inhibitory activity on both tumor cell lines. In the latter experiment, the final concentration of DMSO was maintained equal to $1 \%$, higher concentrations of DMSO being cytotoxic in cell proliferation assays.

Physicochemical Characterization. To assess whether differences in the physicochemical properties of the two diastereoisomers might account, at least in part, for their different antiproliferative activity, we measured the actual concentration of 9 and 11 when dissolved at $10 \mu \mathrm{M}$ in cell culture medium plus 1\% DMSO. While a concentration of 10.7 $( \pm 0.8) \mu \mathrm{M}$ was obtained for compound 11, compound 9 was at least 5-fold less soluble, with a recovered concentration of 2.1 $( \pm 0.2) \mu \mathrm{M}$.

Moving from these results, we investigated whether the observed difference in solubility could be ascribed to a different ionization for the two compounds. The values of aqueous dissociation constants $\left(p K_{a}\right)$ were extrapolated by the potentiometric $\mathrm{pH}$-metric method, starting from mixtures of methanol and water in the $40-10 \%$ range. Nonlinear multiparametric analysis of the titration curves revealed the presence of one ionization site, with $\mathrm{p} K_{\mathrm{a}}$ values of $9.08( \pm 0.05)$ for compound 9 and $9.04( \pm 0.08)$ for compound 11, ruling out this property as the basis for the differences in solubility.

The role of divalent cations ( uch as $\mathrm{Ca}^{2+}$ or $\mathrm{Mg}^{2+}$ ) that are present in the biological assay conditions and could negatively influence the solubility through the formation of complexes was then investigated. The kinetic solubility of compound 9 was determined in the cell culture medium, adding $2 \mathrm{mM}$ EDTA as chelating agent. No effect of EDTA chelation was observed, as the kinetic solubility value for compound 9 was $1.73( \pm 0.15)$ $\mu \mathrm{M}$, superimposable to the result obtained in absence of EDTA.

As the kinetic solubility value is a nonequilibrium measurement, its dependence on the concentration within the stock solution was evaluated. Two different starting concentrations of compound 9 were tested (i.e., $600 \mu \mathrm{M}$ and $300 \mu \mathrm{M}$ in DMSO stock solution), corresponding to nominal concentrations of the final solutions of 6 and $3 \mu \mathrm{M}$, also employed in the cell proliferation assay. In both cases, we could recover concentrations close to $2 \mu \mathrm{M}$, i.e., $1.7( \pm 0.3) \mu \mathrm{M}$ and $1.4( \pm 0.2) \mu \mathrm{M}$, respectively. It therefore appears that $2 \mu \mathrm{M}$ represents the limit of kinetic solubility for compound 9, a concentration corresponding to the $\mathrm{IC}_{50}$ of compound $\mathbf{1 1}$ for LLC cells. Thus, solubility may represent a determinant in the interpretation of the cell proliferation assay data when 9 is dissolved in cell culture medium at concentrations higher than $2 \mu \mathrm{M}$. However, its incapacity to affect LLC cell proliferation at this and lower concentrations confirms the lack of FGF trap activity of $\mathbf{9}$ when compared to 11 .

In Vivo Study. Compound $\mathbf{1}$ was identified as the first small molecule FGF trap able to inhibit the growth of human FGF- 


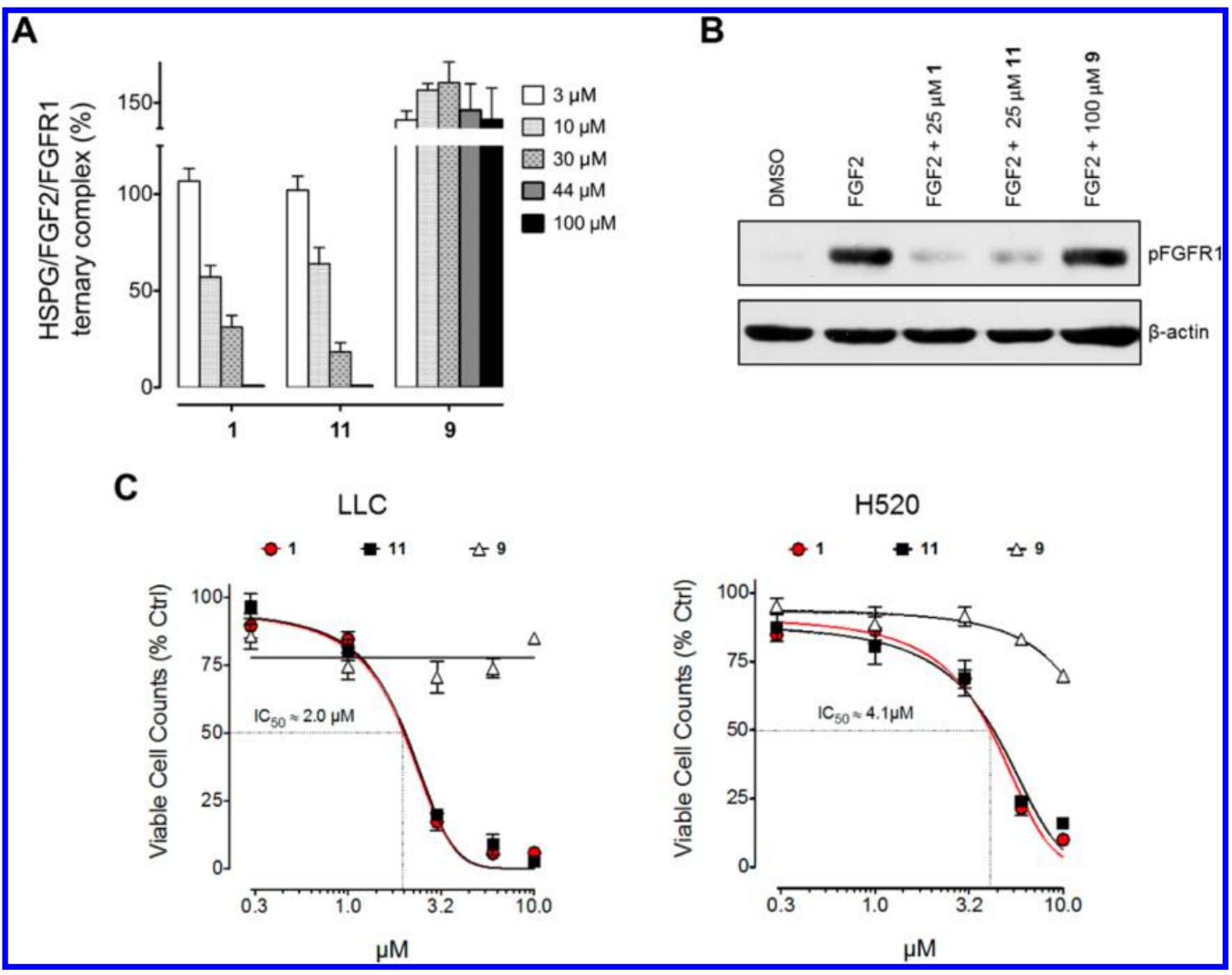

Figure 8. (A) Inhibition of HSPG/FGF2/FGFR1 ternary complexes formation exerted by $\mathbf{1}$ and compounds $\mathbf{9}$ and $\mathbf{1 1}$. (B) Western blot analysis of FGFR1 phosphorylation (pFGFR1) on murine Lewis lung carcinoma (LLC) cells upon stimulation with FGF2 and treatment with compounds 1, 9, and 11. $\beta$-Actin was used for loading normalization. (C) Antiproliferative effect of 1 and compounds 9 and 11 on murine LLC and human lung carcinoma H520 cells.

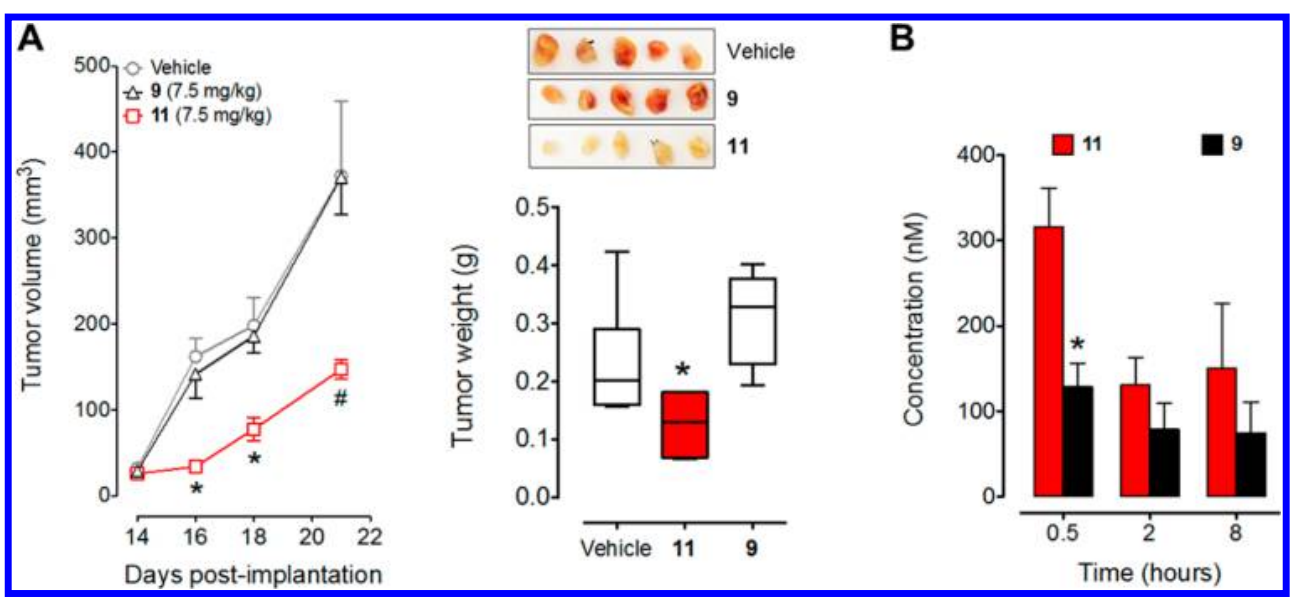

Figure 9. (A) Left panel: inhibition of murine Lewis lung carcinoma tumor growth exerted by oral daily administration of compounds 9, 11, or vehicle. Right panel: tumor picture and weight after administration of 9, 11, or vehicle. (B) Mice plasma concentrations after a single oral administration of $7.5 \mathrm{mg} / \mathrm{kg}$ of 9 or $11:(*) p<0.05,(* *) p<0.01,(\#) p<0.001$.

dependent tumor cells following oral administration in tumorharboring immunodeficient nude mice. ${ }^{14}$ In order to extend these observations in an immunocompetent syngeneic animal model, we designed a study to evaluate whether the different physicochemical and biological properties of compounds 9 and 11 also resulted in a different in vivo antitumor FGF trap activity when administered by oral gavage to syngeneic mice grafted subcutaneously with FGF-driven murine LLC lung carcinoma cells. ${ }^{28}$ In keeping with the in vitro observations, daily treatment by oral gavage with compound $\mathbf{1 1}$ at the dose of $7.5 \mathrm{mg} / \mathrm{kg}$ for 7 days significantly reduced the growth of LLC tumor grafts, while administration of compound 9 did not affect the rate of tumor growth that was indistinguishable from that observed in vehicle-treated animals (Figure 9A). Accordingly, the weight of tumors harvested at the end of experimentation was significantly reduced in the group treated with compound 
11 when compared to the one treated with 9 and control animals (Figure 9A). In addition, in line with the antiangiogenic activity of $\mathbf{1}$, all tumors of animals treated with compound $\mathbf{1 1}$ were less vascularized, as shown by their pale appearance when compared to the reddish appearance of the grafts of the other experimental groups (Figure 9A). Both compounds were well tolerated, as treated mice did not show significant clinical signs of toxicity and body weight changes throughout the whole experimental procedure. The bioavailability of compounds $\mathbf{1 1}$ and 9 following gavage administration in mice was assessed at different time points after administration. The two compounds (Figure 9B) showed a significant difference in their bioavailability. Indeed, the plasma levels of compound $\mathbf{1 1}$ measured $30 \mathrm{~min}$ after a single oral administration of the molecule in adult mice were significantly higher $(\operatorname{Conc}(11,30$ $\min )=316 \pm 45 \mathrm{nM})$ than those measured in the plasma of age-matched animals treated with compound 9 ( Conc $(9,30$ $\min )=128 \pm 28 \mathrm{nM})$. At later time points $(2$ and $8 \mathrm{~h}$ after gavage), plasma levels of compound 11 decreased to values that remained higher than those measured for 9 .

\section{DISCUSSION AND CONCLUSIONS}

Previous observations led to the identification of $\mathbf{1}$ as the first low molecular weight FGF trap molecule. Given its novel mechanism of action and its efficient in vitro and in vivo activity on different FGF-dependent tumor cell lines, 1 may represent a prototype for the development of novel orally available therapeutic agents targeting those tumors where liganddependent FGFR activation represents a key factor. In this paper we described the synthetic procedure for the preparation of 1 that allowed definition and confirmation of its chemical structure, permitting at the same time the identification, isolation, and physicochemical characterization of the two C20 epimers of this steroidal derivative (compounds 11 and 9).

The results demonstrate that compound $\mathbf{1 1}$ recapitulates all the anti-FGF properties described for $\mathbf{1}$, while 9 , obtained as the major isomer, is devoid of a significant FGF trap activity. In particular, 11 acts as an FGF trap molecule able to inhibit FGFR activation, cell proliferation, and tumor growth when tested in vitro and in vivo on FGF-dependent murine and human lung cancer cells, whereas 9 was ineffective. In addition, a relevant point descending from the characterization of the two C20 epimers is that solubility is an issue for the biological activity and bioavailability of these steroidal derivatives.

Despite our efforts, the inability to increase the yield of compound 11 still represents a limitation in the synthetic protocol. Further chemical exploration will be required based on the novel observation that the absolute configuration of C20 represents a crucial point for the structure-activity relationship of the compound.

In conclusion, this first chemical investigation traces the way for the synthesis of new FGF trap small molecules, characterized by improved solubility, to devise relevant structure-activity relationships aimed at the design of new compounds with optimized physicochemical properties and improved potency while retaining the critical oral efficacy and lack of toxicity. These data will constitute the starting point for chemical optimization and structure-activity relationship studies of a promising class of compounds acting as FGF traps with a genuine protein-protein interaction-inhibitor mechanism of action.

\section{EXPERIMENTAL SECTION}

Chemistry. All chemicals were used as received unless stated otherwise. All reactions were performed under a steady overpressure of nitrogen delivered through a balloon. Tetrahydrofuran was distilled over sodium/benzophenone prior to use. Anhydrous solvents such as dichloromethane, $\mathrm{N}, \mathrm{N}$-dimethylformamide, and pyridine were purchased stored over $3 \AA$ molecular sieves and packed under argon. They were subsequently manipulated by syringe under a steady pressure of nitrogen. Column chromatography was performed on silica gel 60 $(0.040-0.063 \mathrm{~mm})$ under forced flow of the appropriate solvent mixtures. TLC analysis was conducted on HPTLC aluminum sheets (Sigma-Aldrich, silica gel 60, $\mathrm{F}_{254}$ ). Compounds were visualized by UV absorption $(245 \mathrm{~nm})$ and/or by dipping in a solution of $\left(\mathrm{NH}_{4}\right)_{6} \mathrm{Mo}_{7} \mathrm{O}_{24} \cdot 4 \mathrm{H}_{2} \mathrm{O} 25 \mathrm{~g} / \mathrm{L}$ and $\left(\mathrm{NH}_{4}\right)_{4} \mathrm{Ce}\left(\mathrm{SO}_{4}\right)_{4} \cdot 2 \mathrm{H}_{2} \mathrm{O} 10 \mathrm{~g} / \mathrm{L}$, in $1 \mathrm{~L}$ of $10 \%$ aqueous $\mathrm{H}_{2} \mathrm{SO}_{4} \cdot{ }^{1} \mathrm{H},{ }^{13} \mathrm{C}$, and ${ }^{19} \mathrm{~F}$ NMR spectra were recorded with Bruker AV 300, 400 and with a Varian 600. Chemical shifts $(\delta$ scale $)$ are reported in parts per million ( $\mathrm{ppm})$ relative to the residual hydrogen peak of the deuterated solvent. Optical rotation was measured with a PerkinElmer 341 polarimeter, the concentration $c$ of the analytes being reported as $\mathrm{mg} / \mathrm{mL}$. Mass spectra were recorded on an Applied Biosystem API-150 EX system spectrometer with an ESI or an APCI interface. Purity of final compounds was analyzed by HPLC with UV detection at $\lambda=220 \mathrm{~nm}$ employing a Shimadzu HPLC gradient system (Shimadzu Corp., Kyoto, Japan) on a Supelco Discovery $\mathrm{C}_{18}$ column $(150 \mathrm{~mm} \times 4.6 \mathrm{~mm}, 5 \mu \mathrm{m}$ particle size $)$ by gradient elution, equipped with two LC-10AD solvent delivery modules, a Rheodyne 7125 sample injector, and a SPD-10A UV-vis detector. Prior to analysis, samples were prepared in $\mathrm{MeOH}$ at a final concentration of $0.1 \mathrm{mg} / \mathrm{mL}$. Flow rate was $1 \mathrm{~mL} / \mathrm{min}$, and injected volume was $10 \mu \mathrm{L}$. Solvent $\mathrm{A}$ : $\mathrm{MeCN}$ with $0.1 \% \mathrm{v} / \mathrm{v}$ of $\mathrm{HCOOH}$. Solvent $\mathrm{B}: \mathrm{H}_{2} \mathrm{O}$ with $0.1 \% \mathrm{v} / \mathrm{v} \mathrm{HCOOH}$. Isocratic conditions were employed for all final compounds: $75 \% \mathrm{~A} / 25 \%$ B. Purity results are presented as $t_{\mathrm{R}}$ (minutes) and relative chemical purity (\%). All tested compounds were $>95 \%$ pure.

$3 \boldsymbol{\beta}$-Hydroxypregn-5-en-20-one (5). ${ }^{29}$ To a solution of pregnenolone acetate $(2.0 \mathrm{~g}, 5.6 \mathrm{mmol})$ in a mixture of $\mathrm{MeOH} / \mathrm{THF}$ (1:1, 60.0 mL), Na (25.8 mg, $1.12 \mathrm{mmol} 0.2$ equiv) was added at room temperature. The reaction was stirred for a total of $4 \mathrm{~h}$, when TLC analysis showed complete consumption of the starting material. The reaction mixture was neutralized with Amberlite IR-120 resin $\left(\mathrm{H}^{+}\right.$ form). The solids were filtered and the solvents removed in vacuo to afford 5 (1.7 g, quant) as a white powder used without any further purification. ${ }^{1} \mathrm{H}$ NMR $\left(300 \mathrm{MHz}, \mathrm{CDCl}_{3}\right) \delta: 5.33(\mathrm{bd}, 1 \mathrm{H}, J=5.2$ $\mathrm{Hz}) ; 3.50(\mathrm{~m}, 1 \mathrm{H}) ; 2.51(\mathrm{t}, 1 \mathrm{H}, J=9.0 \mathrm{~Hz}) ; 2.32-2.15(\mathrm{~m}, 3 \mathrm{H}) ; 2.11$ $(\mathrm{s}, 3 \mathrm{H}) ; 2.05-1.97(\mathrm{~m}, 2 \mathrm{H}) ; 1.88-1.81(\mathrm{~m}, 2 \mathrm{H}) ; 1.71-1.37(\mathrm{~m}, 9 \mathrm{H})$; $1.29-0.93(\mathrm{~m}, 7 \mathrm{H}) ; 0.62(\mathrm{~s}, 3 \mathrm{H}) .{ }^{13} \mathrm{C}$ NMR $\left(100 \mathrm{MHz}, \mathrm{CDCl}_{3}\right) \delta$ : 209.7 ; 140.9; 121.4; 71.6; 63.7; 56.9; 50.0; 44.1; 42.3; 38.9; 37.3; 36.6; $31.9 ; 31.8 ; 31.6 ; 24.5 ; 22.8 ; 21.1 ; 19.4 ; 13.3$. ESI-MS calcd for $\mathrm{C}_{21} \mathrm{H}_{32} \mathrm{O}_{2}$ : 316.24. Found: $317.1[\mathrm{M}+\mathrm{H}]^{+}$.

3 $\beta$-Benzoyloxypregn-5-en-20-one (6). ${ }^{30}$ Pregnenolone 5 (2.5 g, $8.0 \mathrm{mmol})$ was dissolved in pyridine $(30 \mathrm{~mL})$ at $0{ }^{\circ} \mathrm{C}$. Benzoyl chloride $(1.2 \mathrm{~mL}, 10.3 \mathrm{mmol})$ was added, and the reaction mixture was stirred at room temperature for $24 \mathrm{~h}$. The reaction was quenched with $1 \mathrm{M} \mathrm{HCl}$ solution, and the mixture was diluted with DCM $(50 \mathrm{~mL})$. The organic phase was washed with $\mathrm{HCl} 1 \mathrm{M}(20 \mathrm{~mL})$ and brine. After drying over $\mathrm{Na}_{2} \mathrm{SO}_{4}$, the solvent was evaporated under reduced pressure. The crude product was triturated with EtOAc to afford 6 (2.7 $\mathrm{g}, 86 \%)$ as a white crystalline solid. Analytical data correspond to those reported in the literature. ${ }^{30} \mathrm{Mp} 192-193{ }^{\circ} \mathrm{C}$ (lit. $\left.192-193{ }^{\circ} \mathrm{C}\right) .{ }^{1} \mathrm{H}$ NMR $\left(300 \mathrm{MHz}, \mathrm{CDCl}_{3}\right) \delta: 8.05(\mathrm{~d}, 2 \mathrm{H}, J=7.1 \mathrm{~Hz}) ; 7.57(\mathrm{t}, 1 \mathrm{H}, J=$ $7.4 \mathrm{~Hz}) ; 7.45(\mathrm{t}, 1 \mathrm{H}, J=7.7 \mathrm{~Hz}) ; 5.44(\mathrm{bd}, 1 \mathrm{H}, J=4.3 \mathrm{~Hz}) ; 4.87(\mathrm{~m}$, $1 \mathrm{H}) ; 2.57(\mathrm{t}, 1 \mathrm{H}, J=9.1 \mathrm{~Hz}) ; 2.50(\mathrm{~d}, 2 \mathrm{H}, J=7.8 \mathrm{~Hz}) ; 2.26-1.92(\mathrm{~m}$, $8 \mathrm{H}) ; 1.83-1.48(\mathrm{~m}, 8 \mathrm{H}) ; 1.30-1.19(\mathrm{~m}, 3 \mathrm{H}) ; 1.14-1.05(\mathrm{~m}, 4 \mathrm{H})$; $0.66(\mathrm{~s}, 3 \mathrm{H}) .{ }^{13} \mathrm{C}$ NMR $\left(100 \mathrm{MHz}, \mathrm{CDCl}_{3}\right) \delta: 209.7 ; 166.1 ; 139.8$, $132.9 ; 130.9 ; 129.6 ; 128.4 ; 122.6 ; 74.5 ; 63.8 ; 56.9 ; 50.0 ; 44.1 ; 38.9$; $38.2 ; 37.1 ; 36.8 ; 31.9 ; 31.9 ; 31.7 ; 27.9 ; 24.6 ; 22.9 ; 21.2 ; 19.5 ; 13.3$. ESI-MS calcd for $\mathrm{C}_{28} \mathrm{H}_{36} \mathrm{O}_{3}$ : 420.26. Found: $421.1[\mathrm{M}+\mathrm{H}]^{+}$.

Preparation of Hexafluoroacetone. HFA is a colorless, hygroscopic, nonflammable, and highly reactive gas at standard 
pressure and temperature. The only commercial form that we could reasonably access, however, was the liquid trihydrate. A survey of the patent literature suggested the use of strong mineral acids to sequester water from the trihydrate. ${ }^{31}$ After minor optimization, we successfully prepared gaseous HFA by dropping the trihydrate in warm $\left(50{ }^{\circ} \mathrm{C}\right)$ $98 \%$ sulfuric acid under stirring and delivering the liberated gas to the reaction flask through a Teflon tubing by means of a slight overpressure of nitrogen. A picture of the reaction setup is given in the Supporting Information.

3/-Benzoyloxy-21-(bis(trifluoromethyl)hydroxymethyl)pregn-5-en-20-one (7). To a stirred solution of bis-trimethylsilylamine $(550 \mu \mathrm{L}, 2.62 \mathrm{mmol})$ in $\mathrm{THF}(50 \mathrm{~mL})$ at $-78^{\circ} \mathrm{C}$ in a two-neck flask, $\mathrm{BuLi}(1.55 \mathrm{M}$ in hexane, titrated with diphenylacetic acid prior to use, ${ }^{32} 1.6 \mathrm{~mL}, 2.48 \mathrm{mmol}$ ) was added. The mixture was allowed to stir for a total of $30 \mathrm{~min}$. Compound $6(1003.1 \mathrm{mg}, 2.39 \mathrm{mmol})$ was dissolved in dry THF $(10 \mathrm{~mL})$ and added with a syringe to the $-78{ }^{\circ} \mathrm{C}$ cold solution of LiHMDS thus formed under nitrogen atmosphere and allowed to stir for $40 \mathrm{~min}$. In a separate two-neck flask containing $\mathrm{H}_{2} \mathrm{SO}_{4}(98 \%, 10.0 \mathrm{~mL})$ warmed to $50{ }^{\circ} \mathrm{C}$, hexafluoroacetone trihydrate $(3.0 \mathrm{~mL}, 21.5 \mathrm{mmol})$ was added dropwise from a pressure equalizing dropping funnel, under a positive pressure of nitrogen. The gas was delivered to the flask containing the enolate through a Teflon tube with both extremities secured to the second neck of the flasks with a septum. The reaction mixture was allowed reaching room temperature over the course of $4 \mathrm{~h}$. The reaction was quenched with $\mathrm{AcOH}\left(5 \% \mathrm{v} / \mathrm{v}\right.$ in $\left.\mathrm{H}_{2} \mathrm{O}, 10 \mathrm{~mL}\right)$ and diluted with EtOAc $(50 \mathrm{~mL})$. The organic layer was washed with $\mathrm{H}_{2} \mathrm{O}(30 \mathrm{~mL})$ and brine $(30 \mathrm{~mL})$, dried over $\mathrm{Na}_{2} \mathrm{SO}_{4}$, and the solvent was evaporated under reduced pressure. The residue was purified by flash column chromatography $\left(\mathrm{SiO}_{2} \mathrm{Hex} / \mathrm{DCM} 50: 50\right)$ to give $7(1093.6 \mathrm{mg}, 78 \%)$ as a white solid. Mp $181{ }^{\circ} \mathrm{C} .{ }^{1} \mathrm{H}$ NMR $\left(400 \mathrm{MHz}, \mathrm{CDCl}_{3}\right) \delta: 8.04(\mathrm{~d}, 2 \mathrm{H}, J=7.1 \mathrm{~Hz})$; $7.55(\mathrm{t}, 1 \mathrm{H}, J=7.4 \mathrm{~Hz}) ; 7.43(\mathrm{t}, 1 \mathrm{H}, J=7.8 \mathrm{~Hz}) ; 7.08(\mathrm{~s}, 1 \mathrm{H}) ; 5.41$ (bd, $1 \mathrm{H}, J=4.7 \mathrm{~Hz}) ; 4.86(\mathrm{~m}, 1 \mathrm{H}) ; 2.94(\mathrm{~d}, 1 \mathrm{H}, J=17.2 \mathrm{~Hz}) ; 2.80(\mathrm{~d}$, $1 \mathrm{H}, J=17.2 \mathrm{~Hz}) ; 2.61(\mathrm{t}, 1 \mathrm{H}, J=9.0 \mathrm{~Hz}) ; 2.47(\mathrm{bd}, 2 \mathrm{H}, J=7.0 \mathrm{~Hz})$; $2.18(\mathrm{q}, 1 \mathrm{H}, J=9.3 \mathrm{~Hz}) ; 2.04-1.90(\mathrm{~m}, 4 \mathrm{H}) ; 1.79-1.49(\mathrm{~m}, 8 \mathrm{H})$; $1.30-1.20(\mathrm{~m}, 3 \mathrm{H}) ; 1.09-1.04(\mathrm{~m}, 4 \mathrm{H}) ; 0.69(\mathrm{~s}, 3 \mathrm{H}) .{ }^{13} \mathrm{C}$ NMR $(100$ $\left.\mathrm{MHz}, \mathrm{CDCl}_{3}\right) \delta: 212.1 ; 166.1 ; 139.8 ; 132.9 ; 130.8 ; 129.6 ; 128.4 ;$ $\left(127.0 ; 123.9 ; 121.1 ; 118.4\left(\mathrm{CF}_{3}\right)_{2}\right) ; 122.3 ;(76.8 ; 76.5 ; 76.2 ; 75.9$ $\left(\mathrm{COH}\left(\mathrm{CF}_{3}\right)_{2}\right) ; 74.4 ; 64.9 ; 57.0 ; 49.9 ; 45.3 ; 38.7 ; 38.3 ; 37.8 ; 37.1$; $36.7 ; 32.0 ; 31.8 ; 27.9 ; 24.4 ; 22.9 ; 21.1 ; 19.5 ; 13.3 .{ }^{19} \mathrm{~F}$ NMR $(376$ $\left.\mathrm{MHz}, \mathrm{CDCl}_{3}\right) \delta:-78.03(\mathrm{q}, J=9.4 \mathrm{~Hz}),-78.24(\mathrm{q}, J=9.4 \mathrm{~Hz})$. ESIMS calcd for $\mathrm{C}_{31} \mathrm{H}_{36} \mathrm{~F}_{6} \mathrm{O}_{4}: 586.25$. Found: $585.16[\mathrm{M}-\mathrm{H}]^{-}$.

( $20 R)-3 \beta$ - B enzoyloxy- 21 - (b is (trifluoromethyl)hydroxymethyl)pregn-5-en-20-ol (8). Compound 7 (110.2 mg, $0.19 \mathrm{mmol}$ ) was dissolved in $\mathrm{MeOH} / \mathrm{THF}(1: 1 \mathrm{v} / \mathrm{v}, 20 \mathrm{~mL})$, and $\mathrm{NaBH}_{4}(10.3 \mathrm{mg}, 0.27 \mathrm{mmol})$ was added at $0{ }^{\circ} \mathrm{C}$. The reaction was warmed to room temperature and stirred for $1 \mathrm{~h}$, when complete conversion of the starting material was observed by TLC analysis. The reaction was quenched with $\mathrm{HCl}$ solution $(1 \mathrm{M}, 5.0 \mathrm{~mL})$, and stirring was continued for $15 \mathrm{~min}$. Then reaction was diluted with aqueous $\mathrm{NaOH}(2 \mathrm{M}, 30 \mathrm{~mL})$ and stirred for an additional $2 \mathrm{~h}$. After addition of EtOAc $(50 \mathrm{~mL})$, the organic layer was washed with water and brine, dried over $\mathrm{Na}_{2} \mathrm{SO}_{4}$ and the solvent was evaporated under reduced pressure, affording a white solid. The residue was purified by flash chromatography ( $\left.\mathrm{SiO}_{2} \mathrm{Hex} / \mathrm{DCM} 30: 70\right)$ to furnish 8 (80.5 mg, 72\%) as a white powder. $\mathrm{Mp} 252{ }^{\circ} \mathrm{C} .{ }^{1} \mathrm{H} \mathrm{NMR}\left(400 \mathrm{MHz}, \mathrm{CDCl}_{3}\right) \delta: 8.03$ $(\mathrm{d}, 2 \mathrm{H}, J=7.1 \mathrm{~Hz}) ; 7.56(\mathrm{t}, 1 \mathrm{H}, J=7.4 \mathrm{~Hz}) ; 7.44(\mathrm{t}, 1 \mathrm{H}, J=7.8 \mathrm{~Hz})$; $6.77(\mathrm{~s}, 1 \mathrm{H}) ; 5.42(\mathrm{bd}, 1 \mathrm{H}, J=4.8 \mathrm{~Hz}) ; 4.88(\mathrm{~m}, 1 \mathrm{H}) ; 4.21(\mathrm{q}, 1 \mathrm{H}, 9.3$ $\mathrm{Hz}) ; 2.98(\mathrm{~d}, 1 \mathrm{H}, J=7.7 \mathrm{~Hz}) ; 2.48(\mathrm{~m}, 2 \mathrm{H}) ; 2.18(\mathrm{q}, 1 \mathrm{H}, J=9.3 \mathrm{~Hz})$; 2.09-1.92 (m, 6H); 1.81-1.35 (m, 9H); 1.26-1.15 (m, 3H); 1.09$1.040(\mathrm{~m}, 4 \mathrm{H}) ; 0.84(\mathrm{~s}, 3 \mathrm{H}) .{ }^{13} \mathrm{C}$ NMR $\left(100 \mathrm{MHz}, \mathrm{CDCl}_{3}\right) \delta: 166.7$; $139.8 ; 133.2 ; 130.4 ; 129.7$; 128.4 ; $(128.0 ; 127.3 ; 125.1 ; 124.4 ; 122.3$; $\left.121.5 ; 119.2 ; 118.4 ; \quad\left(\mathrm{CF}_{3}\right)_{2}\right) ; 122.6 ; \quad(77.1 ; 76.8 ; 76.5 ; 76.2$ $\left(\mathrm{COH}\left(\mathrm{CF}_{3}\right)_{2}\right) ; 56.9 ; 56.1 ; 50.0 ; 42.6 ; 39.9 ; 38.2 ; 37.2 ; 36.8 ; 33.7$; $31.9 ; 31.7 ; 28.3 ; 27.8 ; 25.4 ; 24.5 ; 21.0 ; 19.5 ; 12.6 .{ }^{19} \mathrm{~F}$ NMR (376 $\left.\mathrm{MHz}, \mathrm{CDCl}_{3}\right) \delta:-75.68(\mathrm{q}, J=9.8 \mathrm{~Hz}),-79.53(\mathrm{q}, J=9.8 \mathrm{~Hz})$. ESIMS calcd for $\mathrm{C}_{31} \mathrm{H}_{38} \mathrm{~F}_{6} \mathrm{O}_{4}$ : 588.27. Found: $587.2[\mathrm{M}-\mathrm{H}]^{-}$.

(20R)-21-(Bis(trifluoromethyl)hydroxymethyl)pregn-5-en3及,20-diol (9). Compound $8(85.3 \mathrm{mg}, 0.14 \mathrm{mmol})$ was dissolved in a mixture of $\mathrm{MeOH} / \mathrm{THF}(2: 1 \mathrm{v} / \mathrm{v})$. $\mathrm{Na}(4.9 \mathrm{mg}, 0.21 \mathrm{mmol})$ was added and the reaction stirred for $1 \mathrm{~h}$. After neutralization with a $1 \mathrm{M}$ $\mathrm{HCl}$ solution, the mixture was diluted with EtOAc and the organic phase was washed with brine $(5 \mathrm{~mL})$, dried over $\mathrm{Na}_{2} \mathrm{SO}_{4}$ and the solvent was evaporated under reduced pressure. The residue was purified by flash column chromatography $\left(\mathrm{SiO}_{2} \mathrm{Hex} / \mathrm{EtOAc} 70: 30\right)$ to afford 9 (64.4 mg, 95\%). Mp $203{ }^{\circ} \mathrm{C}$; $[\alpha]_{\mathrm{D}}{ }^{20}-28.8$ (c 2.88, $\mathrm{CHCl}_{3}$ / $\mathrm{MeOH}=1 / 1) .{ }^{1} \mathrm{H}$ NMR $\left(400 \mathrm{MHz}, \mathrm{CD}_{3} \mathrm{OD}\right) \delta: 5.34(\mathrm{bd}, 1 \mathrm{H}, J=2.8$ $\mathrm{Hz}) ; 4.06(\mathrm{t}, 1 \mathrm{H}, J=10.3 \mathrm{~Hz}) ; 3.39(\mathrm{~m}, 1 \mathrm{H}, J=4.9 \mathrm{~Hz}) ; 2.21(\mathrm{~m}$, $2 \mathrm{H}) ; 2.10(\mathrm{dt}, 1 \mathrm{H}, J=3.5,12.8) ; 2.02-1.92(\mathrm{~m}, 3 \mathrm{H}) ; 1.85(\mathrm{dt}, 1 \mathrm{H}, J=$ $3.54,13.4) ; 1.78(\mathrm{~m}, 1 \mathrm{H}) ; 1.69(\mathrm{~m}, 2 \mathrm{H}) ; 1.57-1.45(\mathrm{~m}, 6 \mathrm{H}) ; 1.29-$ $1.14(\mathrm{~m}, 4 \mathrm{H}) ; 1.09-1.02(\mathrm{~m}, 4 \mathrm{H}) ; 0.96(\mathrm{td}, 1 \mathrm{H}, J=5.2,6.2) ; 0.81(\mathrm{~s}$, $3 \mathrm{H}) .{ }^{13} \mathrm{C}$ NMR $\left(100 \mathrm{MHz}, \mathrm{CD}_{3} \mathrm{OD}\right) \delta: 141.0 ;(128.2 ; 127.5 ; 125.4$; $\left.124.6 ; 122.5 ; 121.8 ; 119.7 ; 119.0 ;\left(\mathrm{CF}_{3}\right)_{2}\right) ; 121.0 ; 76.9 ; 76.8 ; 76.4$ $\left(\mathrm{COH}\left(\mathrm{CF}_{3}\right)_{2}\right) ; 71.1 ; 70.9 ; 56.7 ; 56.3 ; 50.5 ; 42.4 ; 41.7 ; 39.2 ; 37.3$; $36.4 ; 33.5 ; 31.8 ; 31.7 ; 31.0 ; 25.1 ; 24.2 ; 20.7 ; 18.6 ; 11.2 .{ }^{19} \mathrm{~F}$ NMR $(376$ $\left.\mathrm{MHz}, \mathrm{CD}_{3} \mathrm{OD}\right) \delta:-77.18(\mathrm{q}, J=9.9 \mathrm{~Hz}),-80 .(\mathrm{q}, J=9.8 \mathrm{~Hz})$. ESIMS calcd for $\mathrm{C}_{24} \mathrm{H}_{34} \mathrm{~F}_{6} \mathrm{O}_{3}: 484.24$. Found: $483.3[\mathrm{M}-\mathrm{H}]^{-}$. HPLCUV purity: $t_{\mathrm{R}}=6.6 \mathrm{~min}, 96 \%$.

( $20 S$ ) - $3 \beta$-Benzoyloxy-21-(bis (trifluoromethyl)hydroxymethyl)pregn-5-en-20-ol (10). Compound 7 (191.6 mg, $0.33 \mathrm{mmol})$ was dissolved in THF $(20 \mathrm{~mL})$, and $\mathrm{Na}(\mathrm{OAc})_{3} \mathrm{BH}(190$ $\mathrm{mg}, 0.9 \mathrm{mmol}$ ) was added at $0{ }^{\circ} \mathrm{C}$. The reaction was warmed to room temperature and stirred for $6 \mathrm{~h}$, when complete conversion of the starting material was observed by TLC analysis. The reaction was quenched with $\mathrm{HCl}$ solution (1 $\mathrm{M}, 5.0 \mathrm{~mL}$ ), and stirring was continued for $15 \mathrm{~min}$. The mixture was diluted with aqueous $\mathrm{NaOH}$ $(2 \mathrm{M}, 30 \mathrm{~mL})$ and stirred for additional $2 \mathrm{~h}$. After addition of EtOAc $(50 \mathrm{~mL})$, the organic layer was washed with water and brine, dried over $\mathrm{Na}_{2} \mathrm{SO}_{4}$ and the solvent was evaporated under reduced pressure, affording a white solid. The residue was purified by flash column chromatography $\left(\mathrm{SiO}_{2} \mathrm{Hex} / \mathrm{EtOAc} 80: 20\right)$. The fractions containing both epimers 8 and 10 were subjected to MPLC (Isolera Dalton, Biotage, gradient $t(0) \mathrm{Hex} / \mathrm{EtOAc}$ 98:2, $t(20) \mathrm{Hex} / \mathrm{EtOAc}$ 80:20, giving $10(21.9 \mathrm{mg}, 11 \%)$ as a white amorphous solid. Mp $256{ }^{\circ} \mathrm{C} .{ }^{1} \mathrm{H}$ $\operatorname{NMR}\left(400 \mathrm{MHz}, \mathrm{CDCl}_{3}\right) \delta: 8.03(\mathrm{~d}, 2 \mathrm{H}, J=7.2 \mathrm{~Hz}) ; 7.55(\mathrm{t}, 1 \mathrm{H}, J=$ $7.4 \mathrm{~Hz}) ; 7.43(\mathrm{t}, 1 \mathrm{H}, J=7.7 \mathrm{~Hz}) ; 6.42(\mathrm{bs}, 1 \mathrm{H}) ; 5.42(\mathrm{bd}, 1 \mathrm{H}, J=4.4$ $\mathrm{Hz}) ; 4.85(\mathrm{~m}, 1 \mathrm{H}) ; 4.21(\mathrm{t}, 1 \mathrm{H}, 9.6 \mathrm{~Hz}) ; 2.47(\mathrm{~d}, 2 \mathrm{H}, J=7.8 \mathrm{~Hz}) ; 2.23$ $(\mathrm{d}, 1 \mathrm{H}, J=15.2 \mathrm{~Hz}) ; 2.04-1.43(\mathrm{~m}, 13 \mathrm{H}) ; 1.35-1.07(\mathrm{~m}, 8 \mathrm{H}) ; 0.85$ $(\mathrm{m}, 1 \mathrm{H}) ; 0.72(\mathrm{~s}, 3 \mathrm{H}) .{ }^{13} \mathrm{C} \mathrm{NMR}\left(100 \mathrm{MHz}, \mathrm{CDCl}_{3}\right) \delta: 116.1,139.7$, 132.8 , 130.7, 129.6, 128.3, 125.0, 122.4, 122.1, 74.5, 72.0, 57.3, 56.4, 49.8, 41.8, 39.0, 37.0, 36.6, 33.6, 31.7, 31.5, 29.7, 27.8, 24.8, 23.9, 20.7, 19.4, 12.5. ${ }^{19} \mathrm{~F}$ NMR $\left(376 \mathrm{MHz}, \mathrm{CDCl}_{3}\right) \delta:-75.45(\mathrm{q}, J=9.8 \mathrm{~Hz})$, $-79.50\left(\mathrm{q}, J=9.8 \mathrm{~Hz}\right.$ ). ESI-MS calcd for $\mathrm{C}_{31} \mathrm{H}_{38} \mathrm{~F}_{6} \mathrm{O}_{4}:$ 588.3. Found: $587.2[\mathrm{M}-\mathrm{H}]^{-}$.

(20S)-21-(Bis(trifluoromethyl)hydroxymethyl)pregn-5-en3及,20-diol (11). Compound $10(85.3 \mathrm{mg}, 0.14 \mathrm{mmol})$ was dissolved in a mixture of $\mathrm{MeOH} / \mathrm{THF}(2: 1 \mathrm{v} / \mathrm{v}) . \mathrm{Na}(4.9 \mathrm{mg}, 0.21 \mathrm{mmol})$ was added and the reaction stirred for $1 \mathrm{~h}$. After neutralization with a $1 \mathrm{M}$ $\mathrm{HCl}$ solution, the mixture was diluted with EtOAc and the organic phase was washed with brine $(5 \mathrm{~mL})$, dried over $\mathrm{Na}_{2} \mathrm{SO}_{4}$ and the solvent was evaporated under reduced pressure. The residue was purified by flash column chromatography $\left(\mathrm{SiO}_{2} \mathrm{Hex} / \mathrm{EtOAc} 80: 20\right)$ giving $55.4 \mathrm{mg}$ of 11 as a white powder $(96 \%) . \mathrm{Mp} 205{ }^{\circ} \mathrm{C}$; $[\alpha]_{\mathrm{D}}{ }^{20}$ -34.5 (c 5.73, $\left.\mathrm{CHCl}_{3} / \mathrm{MeOH}=1 / 1\right) .{ }^{1} \mathrm{H}$ NMR $(400 \mathrm{MHz}, \mathrm{MeOD})$ $\delta: 5.35(\mathrm{bd}, 1 \mathrm{H}, J=5.5 \mathrm{~Hz}) ; 4.05(\mathrm{t}, 1 \mathrm{H}, J=10.3 \mathrm{~Hz}) ; 3.39(\mathrm{~m}, 1 \mathrm{H}, J$ $=4.6 \mathrm{~Hz}) ; 2.24-2.19(\mathrm{~m}, 3 \mathrm{H}) ; 1.98(\mathrm{~m}, 1 \mathrm{H}) ; 1.94-1.86(\mathrm{~m}, 2 \mathrm{H})$; $1.80(\mathrm{~m}, 2 \mathrm{H}) ; 1.72-1.43(\mathrm{~m}, 8 \mathrm{H}) ; 1.28-1.04(\mathrm{~m}, 5 \mathrm{H}) ; 1.02(\mathrm{~s}, 3 \mathrm{H})$; $0.96(\mathrm{td}, 1 \mathrm{H}, J=11.4,4.7) ; 0.72(\mathrm{~s}, 3 \mathrm{H}) .{ }^{13} \mathrm{C} \mathrm{NMR}(100 \mathrm{MHz}$, MeOD) $\delta: 142.4 ;\left(129.6 ; 128.7 ; 126.8 ; 126.0 ; 124.0 ; 123.2 ;\left(\mathrm{CF}_{3}\right)_{2}\right)$; $122.4 ; 76.9 ; 76.8 ; 76.4\left(\mathrm{COH}\left(\mathrm{CF}_{3}\right)_{2}\right) ; 72.6 ; 71.8 ; 59.1 ; 58.1 ; 51.7$; $43.1 ; 42.8 ; 40.6 ; 38.6 ; 37.8 ; 35.0 ; 33.0 ; 32.9 ; 32.4 ; 31.0 ; 26.6 ; 25.0$; $22.1 ; 20.0 ; 12.9 .{ }^{19} \mathrm{~F}$ NMR $\left(376 \mathrm{MHz}, \mathrm{CDCl}_{3}\right) \delta:-76.95(\mathrm{q}, J=10.0$ $\mathrm{Hz}),-80.66(\mathrm{q}, J=10.0 \mathrm{~Hz})$. ESI-MS calcd for $\mathrm{C}_{24} \mathrm{H}_{34} \mathrm{~F}_{6} \mathrm{O}_{3}: 484.2$. Found: $483.3[\mathrm{M}-\mathrm{H}]^{-}$. HPLC-UV purity: $t_{\mathrm{R}}=5.2 \mathrm{~min}, 98 \%$.

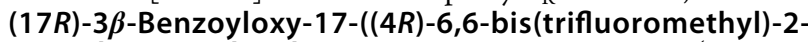
oxo-1,3-dioxan-4-yl)androst-5-ene (12). Compound $8(50.1 \mathrm{mg}$, $0.08 \mathrm{mmol})$ was dissolved in anhydrous DCM $(5 \mathrm{~mL})$ under nitrogen atmosphere before anhydrous pyridine $(70 \mu \mathrm{L}, 0.8 \mathrm{mmol})$ was added. The mixture was cooled to $-50{ }^{\circ} \mathrm{C}$, and triphosgene $(25.3 \mathrm{mg}, 0.08$ $\mathrm{mmol}$ ) was added and stirred for $2 \mathrm{~h}$. Once the mixture was warmed to 
room temperature, to the mixture were added saturated aqueous solution of $\mathrm{NH}_{4} \mathrm{Cl}$ and a $1 \mathrm{M} \mathrm{HCl}$ solution. The mixture was then diluted with EtOAc and the organic phase was washed with brine (5 $\mathrm{mL}$ ) dried over $\mathrm{Na}_{2} \mathrm{SO}_{4}$ and the solvent was evaporated under reduced pressure, affording a white solid $(55 \mathrm{mg})$. The residue was purified by flash column chromatography $\left(\mathrm{SiO}_{2} \mathrm{Hex} / \mathrm{DCM}\right.$ 50:50) giving 12 $(39.8,77 \%)$ as a white powder. $\mathrm{Mp} 268{ }^{\circ} \mathrm{C} .{ }^{1} \mathrm{H}$ NMR $(400 \mathrm{MHz}$, $\left.\mathrm{CDCl}_{3}\right) \delta: 8.04(\mathrm{~d}, 2 \mathrm{H}, J=7.5 \mathrm{~Hz}) ; 7.55(\mathrm{t}, 1 \mathrm{H}, J=7.4 \mathrm{~Hz}) ; 7.43(\mathrm{t}$, $1 \mathrm{H}, J=7.7 \mathrm{~Hz}) ; 5.41(\mathrm{bd}, 1 \mathrm{H}, J=4.7 \mathrm{~Hz}) ; 4.86(\mathrm{~m}, 1 \mathrm{H}) ; 4.44(\mathrm{t}, 1 \mathrm{H}$, $J=10.9 \mathrm{~Hz}) ; 2.47-2.38(\mathrm{~m}, 3 \mathrm{H}) ; 2.21(\mathrm{~m}, 2 \mathrm{H}) ; 2.19(\mathrm{~m}, 3 \mathrm{H}) ; 2.17-$ $1.45(\mathrm{~m}, 9 \mathrm{H}) ; 1.28-1.03(\mathrm{~m}, 8 \mathrm{H}) ; 0.80(\mathrm{~s}, 3 \mathrm{H}) .{ }^{13} \mathrm{C}$ NMR $(100 \mathrm{MHz}$, $\left.\mathrm{CDCl}_{3}\right) \delta: 166.0,144.5,139.9,132.8,130.8,129.5,128.3,122.2,77.4$, 74.4, 55.9, 53.6, 49.9, 42.9, 38.8, 38.2, 37.0, 36.7, 31.8, 31.7, 27.8, 27.3, 24.4, 24.2, 20.7, 19.4, 12.4. ${ }^{19} \mathrm{~F}$ NMR (376 MHz, $\left.\mathrm{CDCl}_{3}\right) \delta:-77.00$ (q, $J=9.4 \mathrm{~Hz}),-78.3(\mathrm{q}, J=9.4 \mathrm{~Hz})$.

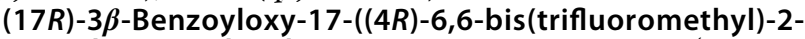
oxo-1,3-dioxan-4-yl)androst-5-ene (13). Compound $10(68.8 \mathrm{mg}$, $0.1 \mathrm{mmol})$ was dissolved in dry DCM $(5 \mathrm{~mL})$ under nitrogen atmosphere before pyridine $(7.0 \mathrm{~mL})$ was added. The mixture was cooled to $-50{ }^{\circ} \mathrm{C}$, and triphosgene $(42.1 \mathrm{mg}, 0.1 \mathrm{mmol})$ was added and stirred for $2 \mathrm{~h}$. Once the mixture was warmed to room temperature, to the mixture were added a saturated aqueous solution of $\mathrm{NH}_{4} \mathrm{Cl}$ and a $1 \mathrm{M} \mathrm{HCl}$ solution. The mixture was then diluted with EtOAc and the organic phase was washed with brine $(5 \mathrm{~mL})$ dried over $\mathrm{Na}_{2} \mathrm{SO}_{4}$ and the solvent was evaporated under reduced pressure, affording a white solid $(65 \mathrm{mg})$. The residue was purified by flash column chromatography $\left(\mathrm{SiO}_{2} \mathrm{Hex} /\right.$ EtOAc $\left.95: 5\right)$ giving 13 (48.9 mg, $68 \%)$ as a white powder. $\mathrm{Mp} 220{ }^{\circ} \mathrm{C} .{ }^{1} \mathrm{H} \mathrm{NMR}\left(400 \mathrm{MHz}, \mathrm{CDCl}_{3}\right) \delta$ : $8.04(\mathrm{~d}, 2 \mathrm{H}, J=7.3 \mathrm{~Hz}) ; 7.55(\mathrm{t}, 1 \mathrm{H}, J=7.4 \mathrm{~Hz}) ; 7.43(\mathrm{t}, 1 \mathrm{H}, J=7.6$ $\mathrm{Hz}) ; 5.42(\mathrm{bd}, 1 \mathrm{H}, J=4.6 \mathrm{~Hz}) ; 4.86(\mathrm{~m}, 1 \mathrm{H}) ; 4.21(\mathrm{t}, 1 \mathrm{H}, J=9.5 \mathrm{~Hz})$; $2.56(\mathrm{~d}, 1 \mathrm{H}, J=13.9 \mathrm{~Hz}) ; 2.47(\mathrm{~m}, 1 \mathrm{H}) ; 2.21(\mathrm{t}, 1 \mathrm{H}, J=12.9) ; 2.10-$ $1.99(\mathrm{~m}, 3 \mathrm{H}) ; 1.91(\mathrm{dt}, 1 \mathrm{H}, J=13.3,3.4 \mathrm{~Hz}) ; 1.82-1.43(\mathrm{~m}, 10 \mathrm{H})$; $1.34-1.01(\mathrm{~m}, 7 \mathrm{H}) ; 0.74(\mathrm{~s}, 3 \mathrm{H}) .{ }^{13} \mathrm{C} \mathrm{NMR}\left(100 \mathrm{MHz}, \mathrm{CDCl}_{3}\right) \delta$ : $166.0,144.9,139.6,132.8,130.8,129.5,128.3,122.9,122.7,122.4$, $120.7,119.8,79.3,79.0,78.0,74.4,56.1,54.0,49.8,41.9,38.8,38.2$, $37.0,36.6,31.7,31.4,27.8,27.7,25.1,24.1,20.7,19.4,12.6 .{ }^{19} \mathrm{~F}$ NMR $\left(376 \mathrm{MHz}, \mathrm{CDCl}_{3}\right) \delta:-77.2(\mathrm{q}, J=9.3 \mathrm{~Hz}),-78.2(\mathrm{q}, J=9.3 \mathrm{~Hz})$.

Kinetic Solubility Measurements. Kinetic solubility for compounds 9 and 11 was determined starting from freshly prepared DMSO stock solutions. ${ }^{33}$ To assess solubility in the cell-based assay buffer (DMEM buffer $+0.4 \%$ FBS), an amount of $2 \mu \mathrm{L}$ of each stock solution was added to $198 \mu \mathrm{L}$ of buffer to reach the final nominal concentrations of $10,6,3 \mu \mathrm{M}(9)$ or $10 \mu \mathrm{M}(11)$ in a 96-well plate. In the EDTA-treated samples, $10 \mu \mathrm{M} 9$ was incubated in DMEM buffer + $0.4 \%$ FBS further added with $2 \mathrm{mM}$ EDTA. Final DMSO concentration in samples was $1 \%$. The plate was kept under stirring for $4 \mathrm{~h}(250 \mathrm{rpm}, \mathrm{rt})$. To assess solubility for $\mathbf{9}$ and $\mathbf{1 1}$ in the SPR assay buffer (PBS buffer), DMSO stock solutions of $\mathbf{9}$ and $\mathbf{1 1}$ were added to PBS to reach the final nominal concentrations of 100, 44, 29, 16, 8.9 $\mu \mathrm{M}$. Final DMSO concentration in samples was $3 \%$. Samples were stirred for $5 \mathrm{~min}(250 \mathrm{rpm}, \mathrm{rt})$. At the end of the reported stirring times, all samples were centrifuged $\left(1000 \mathrm{~g}, 3 \mathrm{~min}, 20^{\circ} \mathrm{C}\right)$ to separate undissolved compound, and an aliquot of the supernatant was further diluted 1 to 100 with $\mathrm{MeCN}$ containing the internal standard 8 at the final concentration of $100 \mathrm{nM}$. Samples were further centrifuged $\left(14000 \mathrm{~g}, 10 \mathrm{~min}, 5^{\circ} \mathrm{C}\right.$ ), and an amount of $10 \mu \mathrm{L}$ of the supernatant was injected into the HPLC-MS/MS system for quantification employing the described analytical method.

$\mathrm{p} K_{\mathrm{a}}$ Measurements. The $\mathrm{p} K_{\mathrm{a}}$ values for compounds 9 and 11 were determined by the potentiometric $\mathrm{pH}$-metric method, ${ }^{34}$ employing a Sirius GLpKa instrument (Sirius Analytical Instruments Ltd., Forrest Row, U.K.) equipped with a semimicro combined electrode, quartz precision dispensers, a temperature probe, and a micro mechanical stirrer. As the solubility of the compounds did not allow a direct aqueous determination of $\mathrm{p} K_{\mathrm{a}}$, aqueous $\mathrm{p} K_{\mathrm{a}}$ values were extrapolated starting from cosolvent $\mathrm{pK}_{\mathrm{a}}$ values $\left(\mathrm{psK}_{\mathrm{a}}\right)$ obtained in mixtures of water (at $0.15 \mathrm{M}$ fixed ionic strength for $\mathrm{KCl}$ addition) and methanol in the $40 \%-10 \% \mathrm{w} / \mathrm{v}$ range. All potentiometric titrations were performed at $25.0 \pm 0.1{ }^{\circ} \mathrm{C}$ under a nitrogen atmosphere.
HPLC-ESI-MS/MS Analytical Method. A HPLC-ESI-MS/MS method for the quantitative analysis of compounds 9 and 11 was developed employing a Thermo Accela ultra high performance liquid chromatography (UHPLC) gradient system coupled to a Thermo TSQ Quantum Max triple quadrupole mass spectrometer (Thermo Italia, Milan, Italy) equipped with a heated electrospray ionization (HESI) ion source. Chromatographic separation occurred on a Phenomenex Synergi Fusion column $(100 \mathrm{~mm} \times 2.0 \mathrm{~mm}, 4 \mu \mathrm{m}$ particle size) by gradient elution. Eluent $A$ was acetonitrile; eluent $B$ was water. Gradient: $t(0 \mathrm{~min}), 5 \% \mathrm{~A} / 95 \% \mathrm{~B} . t(1 \mathrm{~min}): 5 \% \mathrm{~A} / 95 \% \mathrm{~B} . t(6$ $\min ): 95 \% \mathrm{~A} / 5 \% \mathrm{~B} . t(9 \mathrm{~min}): 95 \% \mathrm{~A} / 5 \% \mathrm{~B} . t(11 \mathrm{~min}): 5 \% \mathrm{~A} / 95 \% \mathrm{~B}$, with a 3 min re-equilibration time. Mass spectrometric analyses were done in negative ion mode and in multiple reaction monitoring (MRM). $\mathrm{H}$ ESI interface parameters were set as follows: probe middle (D) position; capillary temperature $270{ }^{\circ} \mathrm{C}$; spray voltage $3.0 \mathrm{kV}$. Nitrogen was used as nebulizing gas at the following pressure: sheath gas, $35 \mathrm{psi}$; auxiliary gas, 15 arbitrary units (a.u.). Argon was used as the collision gas at a pressure of approximately 1.5 mTorr. For quantitative analysis, the following parent ion $\rightarrow$ product ions transitions were selected. 9: $m / z 483.1 \rightarrow m / z 413.3+m / z 111.0+m / z 69.1$ (tube lens 74; collision energies $22,25,74 \mathrm{eV}$, respectively; retention time $\left(t_{\mathrm{R}}\right), 7.50$ $\min$ ). 11: $m / z 483.1 \rightarrow m / z 413.3+m / z 111.0+m / z 69.1$ (tube lens 74; collision energies $22,25,74 \mathrm{eV}$, respectively; retention time, 7.33 min). 8 (internal standard): $m / z 587.1 \rightarrow m / z 517.5+m / z 499.6+$ $\mathrm{m} / z 111.0$ (tube lens 93; collision energies 22, 30, $25 \mathrm{eV}$ ). Calibration curves for the analyte were prepared by spiking blank mouse plasma with stock solutions of 9 or 11 in DMSO. Both calibration and unknown samples were processed by protein precipitation via organic solvent addition (acetonitrile containing the internal standard; ratio 1:2). Samples were centrifuged ( $13000 \mathrm{rpm}, 10 \mathrm{~min}, 4^{\circ} \mathrm{C}$ ), and an amount of $10 \mu \mathrm{L}$ of the supernatant was injected into the HPLC-ESIMS/MS system for quantification. Linearity was checked in the 500-1 $\mathrm{nM}$ concentration range, with a LOQ equal to $1 \mathrm{nM}$. The coefficients of correlation $\left(r^{2}\right)$ were $>0.99$ for all curves. The specificity of the assay was evaluated by comparison of HPLC-ESI-MS/MS chromatograms of compounds $\mathbf{9}$ and $\mathbf{1 1}$ at the LOQ to those of blank plasma samples. Extraction efficiency was determined by comparing the peak area ratio of spiked mouse plasma samples at three concentration levels (low, intermediate, and high) to those of extracted blank plasma spiked with the corresponding concentrations. The mean extraction recovery ranged between $90 \%$ and $95 \%$.

Computational Methods. The structures of compounds 9, 11, 12, and 13 were built with Maestro 9.7, ${ }^{24}$ and their geometries were optimized with OPLS2005 force field in combination with an implicit solvent model (water) using a convergence criterion for energy minimization of $0.05 \mathrm{kcal} \mathrm{mol}^{-1} \AA^{-1}$. $^{35}$

A model of FGF2 was built, by the Protein Preparation Wizard of Maestro 9.7, from the crystal coordinates of a ternary FGF2-FGFR1heparin complex (PDB code 1fq9). In the final structure, the $\mathrm{C}$ and $\mathrm{N}$ termini were capped with a methylamino and an acetyl group, respectively; glutamate and aspartate residues were deprotonated, lysines and arginines were protonated, and histidines were in their neutral form. Amino acid polar side chains and water molecules were reoriented to optimize the overall hydrogen-bond network. Prior to docking simulations, all molecules different from FGF2 of the first subunit were removed.

Docking studies were performed with Glide $6.1 .^{36}$ The docking grid on the surface of FGF2 was centered on the residues that interact with the ligand in the binding mode described in a previous work, ${ }^{14}$ i.e., Leu55, Ala57, Val63, Glu96, and Leu98. The bounding box, enclosing ligand center of mass, was extended for $15 \AA$ in each axis. Docking simulations were performed in standard precision mode, imposing a hydrogen bond constraint on the carboxylate group of Glu96. van der Waals radii of the ligand were scaled to 0.7. One-hundred poses were collected for each compound, avoiding multiple solutions of similar poses.

We adopted residue numbering from mature FGF2, which is also used in the PDB file. The previous work had adopted a different numbering, with a positive shift of nine units (Leu64, Ala66, Val72, Glu105, and Leu107). 
Biology Reagents and Cell Cultures. Human recombinant FGF2 was from Tecnogen (Piana di Monteverna, Caserta, Italy). Murine Lewis lung carcinoma (LLC), cultured in DMEM plus $10 \%$ heat-inactivated FBS, were provided by R. Giavazzi (Istituto M. Negri, Milan, Italy). Human H520 cells were obtained from ATCC and cultured in RPMI plus 10\% FBS. Cells were maintained at low passage, returning to original frozen stocks every 3-4 months, and tested regularly for Mycoplasma negativity.

Surface Plasmon Resonance (SPR). Compounds 9 and 11 were analyzed for their capacity to directly bind to immobilized FGF2 using a BIAcore X-100 apparatus (BIAcore Inc., Piscataway, NJ, USA). FGF2 $(20 \mu \mathrm{g} / \mathrm{mL}$ in $10 \mathrm{mM}$ sodium acetate, $\mathrm{pH} 6.0)$ was allowed to react with a flow cell of a CM5 sensor chip previously activated with a mixture of $0.2 \mathrm{M} \mathrm{N}$-ethyl- $\mathrm{N}^{\prime}$-(3-dimethylaminopropyl)carbodiimide hydrochloride and $0.05 \mathrm{M} \mathrm{N}$-hydroxysuccinimide $(35 \mu \mathrm{L}$, flow rate 10 $\mu \mathrm{L} / \mathrm{min})$. After ligand immobilization, matrix neutralization was performed with $1.0 \mathrm{M}$ ethanolamine $(\mathrm{pH} 8.5)$ ( $35 \mu \mathrm{L}$, flow rate 10 $\mu \mathrm{L} / \mathrm{min}$ ) and the activated/deactivated dextran was used as reference (control) system. Increasing concentrations of 9 and 11 (ranging between 8 and $150 \mu \mathrm{M}$ ) were injected over the FGF2-coated sensor chip, and the response was recorded as a function of time-tracking the SPR intensity change upon binding progression. Injection lasted for 4 min (flow rate $30 \mu \mathrm{L} / \mathrm{min}$ ) to allow association to immobilized FGF2 and was followed by $10 \mathrm{~min}$ of dissociation; each run was performed in $3 \%$ DMSO in PBS and the sensor chip was regenerated with $10 \mathrm{mM}$ $\mathrm{NaOH}$. The equilibrium (plateau) values of the SPR sensorgrams were used to build the binding isotherms displayed, after normalization. Binding isotherm points were fitted with the Langmuir equation for monovalent binding to evaluate the mass surface dissociation constant, $K_{\mathrm{d}}$. The best-fitting procedure was performed with the SigmaPlot 11.0 software package (Systat Software Inc.).

HSPG/FGF/FGFR1 Mediated Cell-Cell Adhesion Assay. This assay was performed as described with minor modifications. ${ }^{37}$ Briefly, wild-type CHO-K1 cells were seeded in 24-well plates at 150000 cells $/ \mathrm{cm}^{2}$. After $24 \mathrm{~h}$, cell monolayers were washed with PBS and incubated with $3 \%$ glutaraldehyde in PBS for $2 \mathrm{~h}$ at $4{ }^{\circ} \mathrm{C}$. Fixation was stopped with $0.1 \mathrm{M}$ glycine, and cells were washed extensively with PBS. Then, A745-CHO-flg-1A-luc cells $\left(50000 \mathrm{cells} / \mathrm{cm}^{2}\right)$ were added to $\mathrm{CHO}-\mathrm{K} 1$ monolayers in serum-free medium plus $10 \mathrm{mM}$ EDTA with or without $30 \mathrm{ng} / \mathrm{mL}$ of FGF2 in the absence or presence of increasing concentrations of 1, 11, or 9 dissolved in 3\% DMSO. After $2 \mathrm{~h}$ of incubation at $37^{\circ} \mathrm{C}$, unattached cells were removed by washing twice with PBS, A745-CHO-flg-1A-luc cells bound to the CHO-K1 monolayer were solubilized, and luciferase activity was quantified. All experiments were performed in triplicate.

Western Blotting. LLC cells were treated with FGF2 $(30 \mathrm{ng} / \mathrm{mL})$ in the absence or presence of compound 1, 9, or 11 dissolved in culture medium and 3\% DMSO. After $20 \mathrm{~min}$ of incubation, cell samples were washed in cold PBS and homogenized in RIPA buffer containing $1 \%$ Triton-X100, $0.2 \%$ BriJ, $1 \mathrm{mM}$ sodium orthovanadate, and protease inhibitors cocktail. Protein concentrations were determined using the Bradford protein assay (Bio-Rad Laboratories, Milano, Italy). Blotting analysis was performed using antiphospho FGFR1 (Santa Cruz Biotechnology, Santa Cruz, CA, USA). Equal loading of the lanes was confirmed by immunoblotting with anti- $\beta$ actin antibody.

Viable Cell Counting. Cells were cultured under appropriate conditions for $48 \mathrm{~h}$ (LLC cells) or $72 \mathrm{~h}$ (H520 cells) in the absence or presence of compound 1, 9, or 11 dissolved in culture medium and $1 \%$ DMSO. Propidium iodide (PI) staining (Immunostep, Salamanca, SP, EU) was used to detect PI-negative viable cells by flow cytometry. Absolute cell counts were obtained by the counting function of the MACSQuant analyzer (Miltenyi Biotec).

In Vivo Studies. Animal experiments were performed in accordance with the institutional and national guidelines and regulations. Eight-week-old C57BL/6 mice were injected sc into the dorsolateral flank with $5 \times 10^{5} \mathrm{LLC}$ cells in $200 \mu \mathrm{L}$ total volume of PBS. When tumors were palpable, 11 or 9 (both at $7.5 \mathrm{mg} / \mathrm{kg}$ ) or vehicle was administered daily by gavage in a $200 \mu \mathrm{L}$ final volume of DMSO $/ \mathrm{H}_{2} \mathrm{O}$ (1:1, vol:vol). Tumors were measured in two dimensions, and tumor volume was calculated according to the formula $V=\left(D \times d^{2}\right) / 2$, where $D$ and $d$ are the major and minor perpendicular tumor diameters, respectively. ${ }^{28}$ At the end of the experimental procedure, tumors were harvested, weighed, and photographed. For the determination of plasma levels of compounds 9 and 11, eight-week-old C57BL76 mice were treated orally with 7.5 $\mathrm{mg} / \mathrm{kg}$ of each compound and blood samples were collected $30 \mathrm{~min}, 2$ $\mathrm{h}$, and $8 \mathrm{~h}$ thereafter for plasma analysis.

Statistical Analyses. Statistical analyses were performed using the statistical package Prism 5 (GraphPad Software). Student's $t$ test for unpaired data (two-tailed) was used to test the probability of significant differences between two groups of samples. For more than two groups of samples, data were statistically analyzed with a one-way analysis of variance, and individual group comparisons were evaluated by the Bonferroni multiple comparison test. Tumor volume data were statistically analyzed with a two-way analysis of variance, and individual group comparisons were evaluated by the Bonferroni correction. Differences were considered significant when $P<0.05$.

\section{ASSOCIATED CONTENT}

\section{Supporting Information}

The Supporting Information is available free of charge on the ACS Publications website at DOI: 10.1021/acs.jmedchem.5b02021.

NMR and mass spectra of relevant compounds, kinetic solubility, and synthesis information (PDF)

Molecular formula strings (CSV)

\section{AUTHOR INFORMATION}

\section{Corresponding Authors}

*M.P.: phone, +39 030 3717311; fax, +39 030 3717747; e-mail, marco.presta@unibs.it.

*M.M.: phone, +39 0521 905059; fax, +39 0521 905006; email, marco.mor@unipr.it.

*R.R.: phone, +39 030 3717735; fax, +39 030 3717747; e-mail, roberto.ronca@unibs.it.

\section{Author Contributions}

The manuscript was written through contributions of all authors. All authors have given approval to the final version of the manuscript.

\section{Notes}

The authors declare no competing financial interest.

\section{ACKNOWLEDGMENTS}

This work was supported by grants from Ministero Istruzione, Università e Ricerca (FIRB Project RBAP11H2R9 2011), Associazione Italiana Ricerca sul Cancro (AIRC Grant 14395) to M.P., and S.M. was supported by Fondazione Italiana per la Ricerca sul Cancro Fellowships.

\section{ABBREVIATIONS USED}

CHO, Chinese hamster ovary; DCM, dichloromethane; DiBAL-H, diisobutylaluminum hydride; DMEM, Dulbecco's modified Eagle medium; EDTA, ethylenediaminetetraacetic acid; FBS, fetal bovine serum; FGF2, fibroblast growth factor 2; FGFR, fibroblast growth factor receptor; HFA, hexafluoroacetone; HMDS, hexamethyldisilylamine; HSPG, heparan sulfate proteoglycan; LiHMDS, lithium hexamethildisilylamide; MPLC, medium pressure liquid chromatography; NMR, nuclear magnetic resonance; NOE, nuclear Overhauser effect; PBS, phosphate buffered saline; RPMI, Rosewell Park Memorial Institute; THF, tetrahydrofuran; TK, tyrosine kinase 


\section{REFERENCES}

(1) Bikfalvi, A.; Klein, S.; Pintucci, G.; Rifkin, D. B. Biological roles of fibroblast growth factor-2. Endocr. Rev. 1997, 18, 26-45.

(2) Schlessinger, J.; Plotnikov, A. N.; Ibrahimi, O. A.; Eliseenkova, A. V.; Yeh, B. K.; Yayon, A.; Linhardt, R. J.; Mohammadi, M. Crystal structure of a ternary FGF-FGFR-Heparin complex reveals a dual role for heparin in FGFR binding and dimerization. Mol. Cell 2000, 6, $743-750$.

(3) Beenken, A.; Mohammadi, M. The FGF family: biology, pathophysiology and therapy. Nat. Rev. Drug Discovery 2009, 8, 235-253.

(4) (a) Folkman, J.; Klagsbrun, M. Angiogenic factors. Science 1987, 235, 442-447. (b) Presta, M.; Dell'Era, P.; Mitola, S.; Moroni, E.; Ronca, R.; Rusnati, M. Fibroblast growth factor/fibroblast growth factor receptor system in angiogenesis. Cutokine Growth Factor Rev. 2005, 16, 159-178. (c) Brooks, A. N.; Kilgour, E.; Smith, P. D. Molecular pathways: fibroblast growth factor signaling: a new therapeutic opportunity in cancer. Clin. Cancer Res. 2012, 18, 18551862.

(5) Morrison, R. S.; Shi, E.; Kan, M.; Yamaguchi, F.; McKeehan, W.; Rudnicka-Nawrot, M.; Palczewski, K. Inositol hexakisphosphate (InsP6): an antagonist of fibroblast growth factor receptor binding and activity. In Vitro Cell. Dev. Biol.: Anim. 1994, 30A, 783-789.

(6) Hu, M.-M.; Hu, Y.; Gao, G.-K.; Han, Y.; Shi, G.-L.; Li, B.-I. Basic fibroblast growth factor shows prognostic impact on survival in operable non-small cell lung cancer patients. Thorac. Cancer 2015, 6, 450-457.

(7) Weiss, J.; Sos, M. L.; Seidel, D.; Peifer, M.; Zander, T.; Hueckmann, J. M.; Ullrich, R. T.; Menon, R.; Maier, S.; Soltermann, A.; Moch, H.; Wagener, P.; Fischer, F.; Heynck, S.; Koker, M.; Schöttle, J.; Leenders, F.; Gabler, F.; Dabow, I.; Querings, S.; Heukamp, L. C.; Balke-Want, H.; Ansén, S.; Rauh, D.; Baessmann, I.; Altmüller, J.; Wainer, Z.; Conron, M.; Wright, G.; Russell, P.; Solomon, B.; Brambilla, E.; Brambilla, C.; Lorimier, P.; Sollberg, S.; Brustugun, O. T.; Engel-Riedel, W.; Ludwig, C.; Petersen, I.; Sänger, J.; Clement, J.; Groen, H.; Timens, W.; Sietsma, H.; Thunnissen, E.; Smit, E.; Heideman, D.; Cappuzzo, F.; Ligorio, C.; Damiani, S.; Hallek, M.; Beroukhim, R.; Pao, W.; Klebl, B.; Baumann, M.; Buettner, R.; Ernestus, K.; Stoelben, E.; Wolf, J.; Nürnberg, P.; Perner, S.; Thomas, R. K. Frequent and focal FGFR1 amplification associates with therapeutically tractable FGFR1 dependency in squamous cell lung cancer. Sci. Transl. Med. 2010, 2, 62 ra93.

(8) (a) Burbridge, M. F.; Bossard, C. J.; Saunier, C.; Fejes, I.; Bruno, A.; Léonce, S.; Ferry, G.; Da Violante, G.; Bouzom, F.; Cattan, V.; Jacquet-Bescond, A.; Comoglio, P. M.; Lockhart, B. P.; Boutin, J. A.; Cordi, A.; Ortuno, J. C.; Pierré, A.; Hickman, J. A.; Cruzalegui, F. H.; Depil, S. S49076 is a novel kinase inhibitor of MET, AXL, and FGFR with strong preclinical activity alone and in association with bevacizumab. Mol. Cancer Ther. 2013, 12, 1749-1762. (b) Ho, H. K.; Yeo, A. H.; Kang, T. S.; Chua, B. T. Current strategies for inhibiting FGFR activities in clinical applications: opportunities, challenges and toxicological considerations. Drug Discovery Todav 2014, 19, 51-62. (c) Ronca, R.; Benzoni, P.; Leali, D.; Urbinati, C.; Belleri, M.; Corsini, M.; Alessi, P.; Coltrini, D.; Calza, S.; Presta, M.; Dell'Era, P. Antiangiogenic activity of a neutralizing human singlechain antibody fragment against fibroblast growth factor receptor 1 . Mol. Cancer Ther. 2010, 9, 3244-3253.

(9) Dieci, M. V.; Arnedos, M.; Andre, F.; Soria, J. C. Fibroblast growth factor receptor inhibitors as a cancer treatment: from a biologic rationale to medical perspectives. Cancer Discovery 2013, 3, 264-279.

(10) (a) Harding, T. C.; Long, L.; Palencia, S.; Zhang, H.; Sadra, A.; Hestir, K.; Patil, N.; Levin, A.; Hsu, A. W.; Charych, D.; Brennan, T.; Zanghi, J.; Halenbeck, R.; Marshall, S. A.; Qin, M.; Doberstein, S. K.; Hollenbaugh, D. W.; Kavanaugh, W. M.; Williams, L. T.; Baker, K. P. Blockade of nonhormonal fibroblast growth factors by FP-1039 inhibits growth of multiple types of cancer. Sci. Transl. Med. 2013, 5, 178 ra39.

(11) Inforzato, A.; Baldock, C.; Jowitt, T. A.; Holmes, D. F.; Lindstedt, R.; Marcellini, M.; Rivieccio, V.; Briggs, D. C.; Kadler, K. E.;
Verdoliva, A.; Bottazzi, B.; Mantovani, A.; Salvatori, G.; Day, A. J. The angiogenic inhibitor long pentraxin PTX3 forms an asymmetric octamer with two binding sites for FGF2. I. Biol. Chem. 2010, 285, 17681-17692.

(12) (a) Giacomini, A.; Matarazzo, S.; Pagano, K.; Ragona, L.; Rezzola, S.; Corsini, M.; Di Salle, E.; Presta, M.; Ronca, R. A long pentraxin-3-derived pentapeptide for the therapy of FGF8b-driven steroid hormone-regulated cancers. Oncotarget 2015, 6, 13790-13802. (b) Leali, D.; Bianchi, R.; Bugatti, A.; Nicoli, S.; Mitola, S.; Ragona, L.; Tomaselli, S.; Gallo, G.; Catello, S.; Rivieccio, V.; Zetta, L.; Presta, M. Fibroblast growth factor 2-antagonist activity of a long-pentraxin 3derived anti-angiogenic pentapeptide. I. Cell. Mol. Med. 2010, 14, 2109-2121.

(13) Developmental Therapeutics Program, NCI/NIH. https://dtp. cancer.gov/.

(14) Ronca, R.; Giacomini, A.; Di Salle, E.; Coltrini, D.; Pagano, K.; Ragona, L.; Matarazzo, S.; Rezzola, S.; Maiolo, D.; Torrella, R.; Moroni, E.; Mazzieri, R.; Escobar, G.; Mor, M.; Colombo, G.; Presta, M. Long-pentraxin 3 derivative as a small-molecule FGF trap for cancer therapy. Cancer Cell 2015, 28, 225-239.

(15) On the basis of the NCI structure, only one option is available for the steroidal skeleton: a pregnane-type, with no ambiguities regarding the ring junction owing to the $\Delta^{5,6}$-unsaturation.

(16) Given the lower priority of the entering group, the attack on the si face leads to the $20 \mathrm{R}$ diastereoisomer. Typical nucleophilic reducing agents $\left(\mathrm{NaBH}_{4}, \mathrm{LiAlH}_{4}\right.$, borane-dimethylsulfide, etc.) provide the $20 R$ product in high epimeric purity. Midland, M. M.; Kwon, Y. C. Stereochemistry of hydroboration of $\alpha$-chiral olefins and reduction of $\alpha$-chiralketones. An unusual anti-Cram selectivity with dialkylboranes. J. Am. Chem. Soc. 1983, 105, 3725-3727.

(17) In no instances could we observe products arising from the enolization at $\mathrm{C} 17$ (thermodynamic enolate) despite the relatively high temperature needed for the enolization. When kept at lower temperature for longer times, the yield was consistently poor.

(18) Ikeda, M.; Matsumura, H.; Sawada, N.; Hashimoto, K.; Tanaka, T.; Noguchi, T.; Hayashi, M. Synthesis and biological evaluations of C23-modified 26,26,26,27,27,27-F6-vitamin D3 analogues. Bioorg. Med. Chem. 2000, 8, 1809-1817.

(19) Fukase, H.; Horii, S. Synthesis of a branched-chain inosose derivative, a versatile synthon of $\mathrm{N}$-substituted valiolamine derivatives from D-glucose. I. Org. Chem. 1992, 57, 3642-3650.

(20) We excluded different steroidal skeletons, as the ${ }^{1} \mathrm{H}$ NMR spectra were extremely similar and the ESI-MS spectra matched perfectly.

(21) Evans, D. A.; Chapman, K. T.; Carreira, E. M. Direct reduction of $\beta$-hydroxy ketones employing tetramethylammonium triacetoxyborohydride. I. Am. Chem. Soc. 1988, 110, 3560-3578.

(22) Relevant NMR spectra are reported in the Supporting Information

(23) Karplus, M. Vicinal proton coupling in nuclear magnetic resonance. I. Am. Chem. Soc. 1963, 85, 2870-2871.

(24) Maestro, version 9.7; Schrodinger LLC: New York, 2009

(25) Bachers, G. E.; Schaefer, T. Applications of the intramolecular nuclear Overhauser effect in structural organic chemistry. Chem. Rev. 1971, 71, 617-626.

(26) Nicolaou, K. C.; Li, Y.; Sugita, K.; Monenschein, H.; Guntupalli, P.; Mitchell, H. J.; Fylaktakidou, K. C.; Vourloumis, D.; Giannakakou, P.; O'Brate, A. Total synthesis of apoptolidin: completion of the synthesis and analogue synthesis and evaluation. I. Am. Chem. Soc 2003, 125, 15443-15454.

(27) (a) Eckert, H.; Forster, B. Triphosgene, a crystalline phosgene substitute. Angew. Chem. Int. Ed. Engl. 1987, 26, 894-895. (b) Fujiwara, K.; Aki, Y.-I.; Yamamoto, F.; Kawamura, M.; Kobayashi, M.; Okano, A.; Awakura, D.; Shiga, S.; Murai, A.; Kawai, H.; Suzuki, T. Synthesis of the C8-C20 and C21-C30 segments of pectenotoxin 2. Tetrahedron Lett. 2007, 48, 4523-4527.

(28) Euhus, D. M.; Hudd, C.; La Regina, M. C.; Johnson, F. E. Tumor measurement in the nude mouse. I. Surg. Oncol. 1986, 31, 229-234. 
(29) Shingate, B. B.; Hazra, B. G.; Salunke, D. B.; Pore, V. S.; Shirazi, F.; Deshpande, M. V. Stereoselective synthesis and antimicrobial activity of steroidal C-20 tertiary alcohols with thiazole/pyridine side chain. Eur. I. Med. Chem. 2011, 46, 3681-3689.

(30) Giral, F. Synthesis of desoxycorticosterone from pregnenolone. I. Am. Chem. Soc. 1950, 72, 1913-1914.

(31) Bonfield, J. H.; Karsay, B. I. Purification of crude hexafluoroacetone containing nitrogen oxides and sulfur dioxide. Patent US 4473712, 1984.

(32) Kofron, W. G.; Baclawski, L. M. A convenient method for estimation of alkyllithium concentrations. L. Org. Chem. 1976, 41, $1879-1880$

(33) Alsenz, J.; Kansy, M. High throughput solubility measurement in drug discovery and development. Adv. Drug Deliverv Rev. 2007, 59, $546-567$.

(34) Box, K.; Bevan, C.; Comer, J.; Hill, A.; Allen, R.; Reynolds, D. High-throughput measurement of pKa values in a mixed-buffer linear $\mathrm{pH}$ gradient system. Anal. Chem. 2003, 75, 883-892.

(35) Banks, J. L.; Beard, H. S.; Cao, Y.; Cho, A. E.; Damm, W.; Farid, R.; Felts, A. K.; Halgren, T. A.; Mainz, D. T.; Maple, J. R.; Murphy, R.; Philipp, D. M.; Repasky, M. P.; Zhang, L. Y.; Berne, B. J.; Friesner, R. A.; Gallicchio, E.; Levy, R. M. Integrated modeling program, applied chemical theory (IMPACT). I. Comput. Chem. 2005, 26, 1752-1780. (36) Glide, version 6.1; Schrodinger, LLC: New York, NY, 2013.

(37) Ronca, R.; Benzoni, P.; Leali, D.; Urbinati, C.; Belleri, M.; Corsini, M.; Alessi, P.; Coltrini, D.; Calza, S.; Presta, M.; Dell'Era, P. Antiangiogenic activity of a neutralizing human single-chain antibody fragment against fibroblast growth factor receptor 1 . Mol. Cancer Ther. 2010, 9, 3244-3253. 